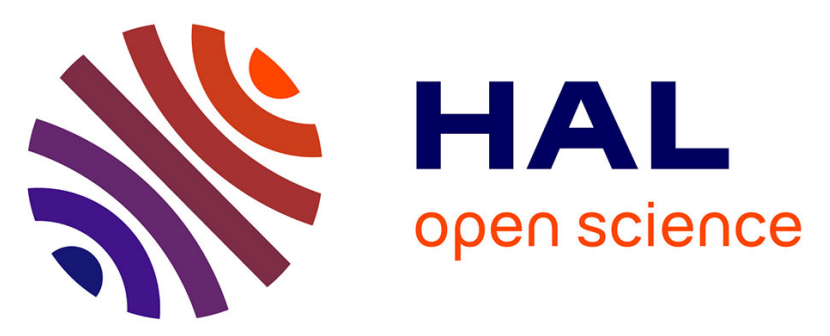

\title{
Triassic tectonics of the Ailaoshan Belt (SW China): Early Triassic collision between the South China and Indochina Blocks, and Middle Triassic intracontinental shearing
}

\author{
Michel Faure, Wei Lin, Yang Chu, Claude Lepvrier
}

\section{To cite this version:}

Michel Faure, Wei Lin, Yang Chu, Claude Lepvrier. Triassic tectonics of the Ailaoshan Belt (SW China): Early Triassic collision between the South China and Indochina Blocks, and Middle Triassic intracontinental shearing. Tectonophysics, 2016, 683, pp.27-42. 10.1016/j.tecto.2016.06.015 . insu01342341

\author{
HAL Id: insu-01342341 \\ https://hal-insu.archives-ouvertes.fr/insu-01342341
}

Submitted on 5 Jul 2016

HAL is a multi-disciplinary open access archive for the deposit and dissemination of scientific research documents, whether they are published or not. The documents may come from teaching and research institutions in France or abroad, or from public or private research centers.
L'archive ouverte pluridisciplinaire HAL, est destinée au dépôt et à la diffusion de documents scientifiques de niveau recherche, publiés ou non, émanant des établissements d'enseignement et de recherche français ou étrangers, des laboratoires publics ou privés.

\section{(ㅇ)(1) $\$$}

Distributed under a Creative Commons Attribution - NonCommercial - NoDerivatives 44.0 
Triassic tectonics of the Ailaoshan Belt (SW China): Early Triassic collision between the South China and Indochina Blocks, and Middle Triassic intracontinental shearing

Michel Faure ${ }^{1}$, Wei Lin ${ }^{2}$, Yang $\mathrm{Chu}^{2}$, Claude Lepvrier ${ }^{3}$

1:Institut des Sciences de la Terre d'Orléans, UMR 7327 CNRS-Université d'Orléans, Campus géosciences, 1A rue de la Férollerie, 45071 Orléans cedex 2, France

2: State Key Laboratory of Lithospheric Evolution, Institute of Geology and Geophysics, Chinese Academy of Sciences, Beijing, China

3: Institut des Sciences de la Terre de Paris, UMR CNRS 7193, Université Pierre-et-MarieCurie, 75252 Paris cedex 5, France

Abstract

In SE Yunnan, the Ailaoshan Belt has been extensively studied for the ductile shearing coeval with the left-lateral Cenozoic activity of the Red River fault. However, the Late Triassic unconformity of the continental red beds upon metamorphic and ductilely deformed rocks demonstrates that the Ailaoshan Belt was already built up by Early Mesozoic tectonics. From West to East, the belt is subdivided into Western, Central, Eastern Ailaoshan, and Jinping zones. The Western Ailaoshan and Central Ailaoshan zones correspond to a Carboniferous-Permian magmatic arc, and an ophiolitic mélange, respectively. The Eastern Ailaoshan, and the Jinping zones consist of deformed Proterozoic basement and Paleozoic to Early Triassic sedimentary cover series both belonging to the South China Block. This lithotectonic zonation indicates that the Ailaoshan Belt developed through a SW-directed 
subduction followed by the collision between Indochina and South China blocks. Crustal thickening triggered per-aluminous magmatism dated at ca 247-240 Ma. Field and microscope-scale top-to-the-NE ductile shearing observed only in the pre-Late Triassic formations, but never in Late Triassic or younger formations, complies with this geodynamic polarity. Furthermore, the late collisional two-mica granitoids and felsic per-aluminous volcanites record a ductile deformation that argues for a continuing crustal shearing deformation after the Early Triassic collision up to the Middle Triassic. Therefore, a twostage tectonic evolution accounts well for the documented structural and magmatic features. The Triassic architecture of the Ailaoshan Belt, and its geodynamic evolution, correlate well to the South and North with the North Vietnam orogens and the Jinshajiang Belt, respectively.

Keywords: Continental collision, ophiolitic mélange, Triassic tectonics, Indosinian orogeny, South China, Indochina

\section{Introduction}

Together with Siberia, Tarim, India, North China, and Indochina, the South China Block (SCB) is one of the main continental masses underlain by a Proterozoic gneissic basement that were welded together during the Phanerozoic to form the present-day Eurasia. The topography of the SCB mostly consists of medium to high-elevation mountain ranges that result of two recent geodynamic events, namely i) the Himalayan collision and the subsequent intracontinental deformation of Asia, and ii) the subduction of the Paleopacific and Philippines Sea plates below the eastern margin of the SCB. However, the high mountain ranges are often located along previous orogenic belts. Thus the knowledge of ancient crustal, and even lithospheric, structures is important to understand the localization of deformation 
zones and their reactivation. The Red River Fault (RRF, Fig. 1) is one of these major lithospheric structures that accommodated the Southeastward extrusion of Sundaland during the Indian indentation (e.g. Tapponnier et al., 1990; Schärer et al., 1994; Leloup et al., 1995; Liu et al., 2015a and enclosed references). When analyzing the Cenozoic deformation, it is useful to distinguish a ductile sinistral Ailaoshan-Red River Shear Zone, and a brittle normal Red River fault. However, since this paper deals with the pre-Late Triassic tectonics, in the following, RRF will be used for simplicity to mention all types of Cenozoic deformation. In its southeastern segment, in SW Yunnan and N. Vietnam, the RRF separates from West to East, the Ailaoshan and Day Nui Con Voi massifs, respectively. Partly due to the intense Cenozoic overprint by the ductile sinistral shearing, the bulk architecture and the pre-Tertiary tectonics of the Ailaoshan Belt remain incompletely documented and thus disputed. At the regional scale of N. Vietnam, the RRF separates a NW belt and a NE belt of Triassic age, sometimes referred to as the Song Ma and Song Chay belts, respectively (e.g. Lepvrier et al., 2011; Faure et al., 2014, and enclosed references). The RRF is a major fault but not a suture zone, i.e. a plate boundary, as the SCB and Indochina were already welded at least since the Early Mesozoic.

In NW Vietnam, the Song Ma fault is widely acknowledged as the suture zone between the South China and Indochina blocks, but the timing of the collision is disputed. Most of authors favor a Triassic collision (e.g. Lepvrier et al., 1997, 2008; Liu et al., 2012a; Nguyen et al., 2013; Faure et al., 2014). Others argue that the Triassic ductile deformation represents an intraplate transcurrent reworking but the real collision occurred in the Early Paleozoic (e.g. Metcalfe, 1996, 2013; Findlay, 1997; Findlay and Pham, 1997; Carter et al., 2001, Carter and Clift, 2008; Roger et al., 2008; Tran and Vu, 2011). Indeed, as recently documented by Lepvrier et al. (2011) and Faure et al. (2014), the question of the suture location between Indochina and SCB appears as a more subtle issue since the Song Ma and 
Song Chay belts are two collisional orogens formed at the same time, and probably belong to the same belt left-laterally offset by the RRF during the Cenozoic (see a discussion on this point in Faure et al., 2014). Another controversial issue is the subduction polarity. Depending on the authors, the SCB belongs either to the upper or lower plate (e.g. Lepvrier et al., 1997, 2008; Nakano et al., 2008; Liu et al. 2012a; Wang et al., 2013; Faure et al., 2014, 2016). Thus the understanding of the correlation between the Ailaoshan and the N. Vietnam belts is a necessary pre-requisite to decipher the pre-Tertiary structure and the evolution of the SCBIndochina collision. This paper aims to present the litho-tectonic zonation and bulk architecture of the Ailaoshan Belt, to correlate these units with those defined in the NW and NE Vietnam orogens, and to discuss its evolution and place in the tectonic framework of the SCB-Indochina collision.

\section{The zonation of the Ailaoshan Belt}

The Ailaoshan Belt is a NW-SE striking, $500 \mathrm{~km}$ long, and 10 to $50 \mathrm{~km}$ wide, triangular area that narrows to the NW and widens to the SE (Fig. 2). The Ailaoshan range separates the Simao basin to the West and the S. China Block to the East. Several NW-SE striking Cenozoic strike-slip or high-angle reverse faults divide the belt into elongated and narrow stripes (e. g. Leloup et al., 1995; Liu et al., 2012b, 2015a; Tang et al., 2013; Lai et al., 2014a, b; Chen et al., 2015; Fig. 2). From West to East, the following litho-tectonic zones are recognized.

\subsection{The Western Ailaoshan zone}

This zone crops out discontinuously SE, W, and NW of Mojiang. From bottom to top, it is characterized by three lithological units overlying the basement (Fig. 3): i) mudstonesiltstone-sandstone turbiditic alternations dated biostratigraphically of Silurian to Devonian; 
ii) a ca $5 \mathrm{~km}$ thick series of volcanic and volcanic-sedimentary rocks of Carboniferous to Late Permian age (e. g. Zhong 2000; Fan et al., 2010); and iii) Late Triassic red beds made of conglomerate, sandstone, and siltstone with unconformable relationships with the underlying units.

The Carboniferous-Permian formations consist of a terrigenous sequence of sandstone, siltstone, siliceous mudstone, and conglomerate with a turbiditic character (Fig. 4A-C). Greywacke and red to green breccia with andesitic, basaltic and dacitic clasts are also well developed. Rare limestones are associated with lava or reworked as pebbles in intraformational conglomerates. The Carboniferous to Permian fusulinids yielded by the carbonated rocks indicate the age of this volcanic-sedimentary series, in agreement with the recent radiometric datings (cf. below).

The volcanic formations consist mostly of andesite, dacite, basaltic andesite, and highAl basalt. Some of these lava flows, intercalated with the sedimentary rocks, exhibit pillow structures (Fig. 4D). The largest exposures of the volcanic sequences crop out in the Wusu and Yaxuanqiao areas, near Mojiang. Detailed petrographic descriptions are given in Fan et al. (2010). Chemical analyses of the volcanites indicate a calc-alkaline signature that complies with a magmatic arc setting (Fan et al., 2010). The Wusu basalt, and the Yaxuanqiao basaltic andesite are dated by SHRIMP method on zircon at $287 \pm 5 \mathrm{Ma}$, and $265 \pm 7 \mathrm{Ma}$, respectively (Jian et al., 2009b; Fan et al., 2010; Fig. 5).

In the southern part of the Western Ailaoshan zone, zircon yields LA-ICP-MS ages at $246 \pm 4 \mathrm{Ma}$ and $273 \pm 5 \mathrm{Ma}$ for the Daheishan dolerite, and at 288 \pm 3 Ma for the Bailu rhyolite (Lai et al., 2014a; Fig. 4). Furthermore, two granitic and granodioritic plutons, named the Pinghe and Xin'anzhai granites, dated at 257 \pm 2 Ma (Lai et al., 2014a), and 255 \pm 2 Ma or $252 \pm 1 \mathrm{Ma}$ (Liu et al., 2015b) correspond to the deep plutonic root of the West Ailaoshan magmatic arc. 


\subsection{The Central Ailaoshan zone}

The Central Ailaoshan Belt is bounded by the Jiujia-Anding, and the Ailaoshan faults to the West and East, respectively (Fig. 2). North of Mojiang, the northern part of the Central Ailaoshan zone consists of an ophiolitic mélange whereas to the South, this unit is hidden below Late Triassic red beds. There, the mafic and ultramafic bodies that are surrounded by the Late Triassic sandstone are possibly olistoliths but outcrop conditions do not allow us to draw a definite conclusion. The Central Ailaoshan zone consists of $\mathrm{m}$ - to km-sized blocks of serpentinized lherzolite, harzburgite, gabbro, dolerite, plagiogranite, basalt, chert, and limestone enclosed into a sandstone-siltstone matrix (Fig. 6). The mafic-ultramafic magmatic rocks and siliceous sedimentary rocks belong to a dismembered ophiolitic series with geochemical affinities of mid-oceanic ridge (Yumul et al., 2008). These ophiolites are interpreted as formed in a small, slow spreading ocean basin. In agreement with previous works (e. g. Shen et al., 1998; Zhong et al., 2000; Lai et al., 2014b), our observations of a "block-in-matrix" formation support the ophiolitic mélange interpretation (Fig. 6).

Zircon from plagiogranite yield contrasted SHRIMP or LA-ICP-MS ages of Early Devonian (365 \pm 7 Ma, Lai et al., 2014b), and Late Carboniferous (328 \pm 16 Ma, Jian et al. 1998). In Pingzhang (Fig. 2), a block of gabbro yields zircon LA-ICP-MS ages at 258 $\pm 6 \mathrm{Ma}$ and 282 $\pm 6 \mathrm{Ma}$ (Lai et al., 2014b). Dolerites are dated of Early Carboniferous at $351 \pm 11 \mathrm{Ma}$, and 334 $\pm 6 \mathrm{Ma}$ (Lai et al., 2014b).

Several biotite granite massifs, such as the Pingzhang and Heping plutons, intrude the Central Ailaoshan zone. These rocks are dated at ca 244 Ma (Lai et al., 2014b). These peraluminous, S-type plutons are interpreted as emplaced in a syncollisional tectonic setting. Rhyolites, ignimbrites, acidic tuffs, pyroclastites and volcanic-sedimentary rocks occupy the southern part of the Central Ailaoshan zone. Near Lüchun, two rhyolites yield similar zircon 
LA-ICP-MS ages at 246 Ma, i.e. at the upper part of the Early Triassic (Lai et al., 2014a). The tectonic significance of this felsic volcanism that is coeval with the per-aluminous plutonism will be discussed below in section 4 .

\subsection{The Eastern Ailaoshan zone}

The Cenozoic NW-SE striking shear zones of the Red River and Ailaoshan faults bound this domain to the NE and the SW, respectively (Leloup et al., 1995). It consists of augen orthogneiss, paragneiss, amphibolite, marble and several generations of acidic and mafic plutons (Figs. 7, 8). Zircon yields LA-ICP-MS ages between $770 \mathrm{Ma}$ and $750 \mathrm{Ma}$ (Qi et al., 2012, 2014). Amphibolites and gneiss are also dated by the same method on zircon around 815-800 Ma (Cai et al., 2014). Moreover, gneiss and migmatite yield zircon ages at $770 \mathrm{Ma}$, $240 \mathrm{Ma}$, and $30 \mathrm{Ma}$ (Lin et al. 2012). Lastly, per-aluminous high-K granite yields $229 \pm 2 \mathrm{Ma}$ ages (Liu et al., 2014). The Cenozoic ages measured in these rocks are obviously related to the magmatic, tectonic, and thermal-metamorphic events coeval with the left-lateral shearing along the RRF system. The Neoproterozoic ages comply with a Precambrian basement. Moreover, the late Middle Triassic ages, at ca $230 \mathrm{Ma}$ of the per-aluminous plutons, indicate that this basement experienced partial melting, as already noted in the Central Ailaoshan zone. On top of the Precambrian metamorphic rocks, a series of an Early to Middle Triassic platy limestone, phyllite and schists crops out locally. This series is interpreted here as the Mesozoic sedimentary cover of the Proterozoic basement (Fig. 9).

\section{4. The Jinping zone}

In the southeastern termination of the Ailaoshan Belt, the Jinping zone is a triangular wedge bounded to the NE and the SW by the sinistral and dextral Sanjiahe, and Tengtiaohe faults, respectively (Fig. 2). This last fault is parallel to the Lao Meng fault that controls the 
opening of a Neogene dextral pull-apart basin. In NW Vietnam, the North-South striking dextral Dien Bien Phu fault represents the northern extension of the Lao Meng fault.

Lithologically, the Jinping zone consists of an early Paleozoic series with Ordovician limestone and mudstone, and Silurian-Devonian turbidite. The most striking rock-type of the Jinping zone is a km-thick series of mafic-ultramafic plutonic rocks, mafic volcanites, including pillow lavas, and volcani-clastites with pillow breccias, basaltic conglomerates, grauwacke and siltstone of Late Permian age (Fig. 7; Wang et al., 2007). An Early Triassic carbonate series covers the Paleozoic formations.

\section{The structure of the Ailaoshan Belt}

The present bulk geometry of the Ailaoshan Belt consists of several compartments juxtaposed by the Cenozoic Red River, Ailaoshan, Jiujia-Anding, and Lixianjiang left-lateral strike slip or thrust faults (Figs. 2, 8). As presented below, this architecture result of two orogenic events, namely: a post-Late Triassic, probably Cenozoic, and a pre-Late Triassic ones.

\subsection{The post-late Triassic deformation.}

In agreement with previous works (e.g. Tapponnier et al., 1990; Leloup et al., 1995; Wang et al., 2000; Searle, 2006; Searle et al., 2010; Liu et al., 2012b, 2015; Tang et al., 2013), the steeply dipping foliation, and subhorizontal stretching lineation commonly developed in the eastern Ailaoshan gneiss is related to the left-lateral ductile shearing of the Red River fault system. A description of these ductile and synmetamorphic structures is beyond the scope of this paper. Furthermore, other left-lateral strike-slip faults are also associated with a ductile deformation. In particular, a subvertical slaty cleavage is observed in 
the Late Triassic red beds (Figs. 9A, B). The bedding-cleavage relationships document upright folding, and suggest a transpressive shearing. Away from these faults, the pre-Triassic formations are also commonly folded. For instance, the Permian formations of the Western Ailaoshan zone exhibit upright parallel folds devoid of cleavage (Fig. 9C) that might be attributed to the Cenozoic tectonics. Moreover, a slaty cleavage is also recognized in the volcanic and sedimentary series (Fig 10). Since these rocks are unmetamorphozed, the age of deformation is difficult to establish.

\subsection{The pre-Late Triassic deformation.}

As shown by the general cross sections of the Ailaoshan Belt, a flat-lying foliation develops in some places of the Eastern Ailaoshan zone, particularly in its southern part where the exposed area is large and the Cenozoic shortening less intense than in the northern part (Fig. 8A, B). The age of this foliation is unknown, available ${ }^{40} \mathrm{Ar} /{ }^{39} \mathrm{Ar}$ ages at ca $28-22 \mathrm{Ma}$ (e. g. Harrison et al., 1996; Wang et al., 2000; Leloup et al., 1995, 2001; Liu et al., 2015a; Chen et al., 2015) argue for a Cenozoic event. However, this date appears as a thermal overprint due to the low closure temperature of the K-Ar chronometer. The bedding-cleavage relationships observed in the Middle Triassic series that overlies the Eastern Ailaoshan gneiss can be interpreted as due either to a tight upright fold, or as the normal limb of a NE-verging fold (Fig. 9E). However, the NE-SW striking stretching lineation observed in the cleavage surface (Fig. 9D) is not in agreement with strike-slip faulting, but on the contrary, complies well with NE-verging folding formed before the Late Triassic.

The ophiolitic mélange of the Central Ailaoshan zone exhibits numerous ductile deformation structures. The terrigenous matrix is pervasively sheared and isoclinally folded (Figs. 10, 11A). The bedding is often transposed into the cleavage (Fig. 11E). The blocks also experienced ductile shearing and isoclinal folding (Fig. 11C). A subhorizontal sigmoidal 
foliation develops in the serpentinized peridotite (Fig. 11B). A stretching lineation is sometimes recognized in both the mélange matrix and blocks. This structure strikes NE-SW, or down-dip, depending if the foliation is flat lying or steeply dipping, respectively (Fig. 10).

In the southern part of the Ailaoshan Belt, South of Lüchun (Fig. 2), the Paleozoic series is ductilely deformed. There, Permian conglomerate and sandstone exhibit a variously dipping foliation, but a consistently NE-SW trending stretching lineation. The asymmetric shape of the clasts, and the development of quartz and mica pressure shadows indicate a topto-the-NE shearing (Fig. 11D). Such a high angle lineation is not in agreement with the strikeslip shearing. In spite of lack of time constraints, a pre-Late Triassic age for these structures is likely, as it is never observed in the overlying Late Triassic red beds. Indeed, in the Late Triassic formations, when present, the stretching lineation is subhorizontal. The late Early Triassic felsic volcanic-sedimentary series that develops north of Lüchun are variously deformed. Although some rocks appear massive and undeformed, in other outcrops, these rocks exhibit a flat lying foliation, when not refolded by later events, and a NE-SW striking stretching lineation.

In conclusion, in spite of the important Cenozoic strike-slip faulting, an older event can be recognized in the Ailaoshan Belt. A top-to-the-NE shearing, inferred from field observation of the classical kinematic indicators, is confirmed by microscopic analyses.

Thin sections perpendicular to the foliation, and parallel to the stretching lineation (i.e. in the $\mathrm{XZ}$ plane of the finite strain ellipsoid) allow us to assess the kinematics related to the pre-Late Triassic deformation. The sandstone and quartzite overlying the eastern Ailaoshan gneiss exhibit typical ductile shear structures such as elongated and asymmetric clasts, quartz ribbons with oblique dynamic recrystallization texture, or asymmetric pressure shadows (Fig. 12A-C). These rocks experienced an intense ductile deformation leading to mylonitic and ultramylonitic fabrics. The classical kinematic indicators unambiguously show a top-to-the- 
NE sense of shear. The same conclusion is inferred from microscopic observations of the sandstone matrix of the ophiolitic mélange. Asymmetric clasts, pressure shadows, oblique dynamic recrystallization fabrics of quartz ribbons indicate a top-to-the-NE sense of shear (Fig. 12 D-F).

The late Early Triassic rhyolite and associated mudstone-siltstone show ductile deformation structures. The apparently undeformed rhyolite presents, in thin section, a blastoporphyritic texture with cracked quartz clasts enclosed in a fine grain recrystallized matrix. Volcanic schist yields sigmoidal opaque minerals, and asymmetric pressure shadows. Sandstone quartz grains are recrystallized and fringed by white mica or quartz pressure shadows (Fig. 13). Therefore, the existence of a top-to-the-NE ductile shearing event older than the deposition of the Late Triassic red beds is well documented both at the field and microscope scales.

\section{Discussion}

\subsection{Timing of the pre-Late Triassic deformation}

On the basis of the structural analysis presented above, the top-to-the-NE shearing would develop after the emplacement of the Triassic felsic magmatism, since these rocks are pervasively foliated. North of Lüchun, a rhyolite yields a zircon U-Pb age at $246 \pm 6 \mathrm{Ma}$ (Lai et al., 2014a). A similar felsic rock is dated by the same method at 246 $\pm 3 \mathrm{Ma}$ in the Western Ailaoshan zone (Lai et al., 2014a). The Tontiange, Heping, and Pingzhan leucogranitic plutons, coeval with the felsic volcanites, are dated at $247 \pm 3 \mathrm{Ma}, 244 \pm 3 \mathrm{Ma}$, and $244 \pm 2 \mathrm{Ma}$, respectively (Liu et al., 2014, Lai et al., 2015b). Thus the existence of a Middle Triassic tectonic event, comprised between $247 \mathrm{Ma}$ (Olenekian) and $215 \mathrm{Ma}$ (Norian), which is the age of the continental red beds, is clearly demonstrated. 
However, geochemical studies of the felsic magmatism show that these rocks are high$\mathrm{K}$ per-aluminous granites. In trace element discrimination diagrams, these felsic magmatic rocks fall in the syn-collision field (Lai et al., 2014a, Liu et al. 2014). In agreement with these results, we argue that the melting of the continental crust that occurred immediately after the collision between the Indochina and South China blocks was responsible for the formation of these S-type plutons, and acidic volcanites. However, as documented in section 3, the Early Triassic magmatic rocks are ductilely deformed in a post-solidus state together with the Middle Triassic carbonates and siltstones before the deposition of the Late Triassic unconformity. Thus, the structural and petrological-geochemical data suggest that collision pre-dated the Early Triassic (ca. $245 \mathrm{Ma}$ ) high-K per-aluminous magmatism, whereas, the ductile shearing involved the Middle Triassic rocks. In order to reconcile the syn-collisional geochemical character of the Early Triassic to early Middle Triassic felsic magmatism and its post-solidus ductile shearing, a two-phase evolution is proposed here. Firstly, in Early Triassic, probably around $250 \mathrm{Ma}$, a top-to-the-NE ductile shearing developed in the Central Ailaoshan ophiolitic mélange. This deformation is related to the continental subduction of the SCB below Indochina. At this time, crustal thickening triggered the per-aluminous melting. Secondly, after the emplacement of the ca 245 Ma syn-collisional magmatism, a new ductile shearing with the same top-to-the-NE kinematics resumed at the end of the Middle Triassic, between $240 \mathrm{Ma}$ and $215 \mathrm{Ma}$. Indeed, these two deformation phases correspond simply to two increments of a single progressive event, globally ascribed to the Indochina-South China blocks collision.

\subsection{Geodynamic interpretation of the Ailaoshan Belt}

A crustal-scale cross section of the Ailaoshan Belt, emphasizing the pre-Late Triassic events, is sketched in Fig. 14. The architecture of the Ailaoshan Belt is a NE-directed stack of 
nappes. In the Eastern Ailaoshan zone, the nappes are mostly developed at the expense of the South China Block, and in the Central Ailaoshan zone they derive from an oceanic domain. The Eastern Ailaoshan zone represents a highly sheared Proterozoic basement. Due to the Cenozoic strike-slip faulting, the Paleozoic to Middle Triassic sedimentary cover of the SCB has been largely disrupted. The Late Permian Jinping alkaline mafic rocks are involved in the deformation as well. The syn-collisional late Early Triassic-early Middle Triassic felsic magmatic rocks are also ductilely deformed. Thus a two-phase evolution, as discussed in the previous section, accounts well for the belt architecture. However, the lack of syn-kinematic metamorphic minerals precludes the precise dating of the tectonic contacts.

From the SW to the NE, the tectonic zones recognized in the Ailaoshan Belt are easily attributed to specific geodynamic domains. The Western Ailaoshan zone, represented by calcalkaline plutons, volcanic, and clastic rocks corresponds to a Permian magmatic arc formed upon the continental crust of the Indochina block. This interpretation is at variance with that of Fan et al. (2010) that relates the East Ailaoshan arc to the subduction of an ocean located to the West of the Indochina Block (in the present coordinates). The Central Ailaoshan ophiolitic mélange is the Carboniferous-Permian subduction complex developed during the subduction of the Paleotethys Ocean. Most of the available radiometric ages for the mafic rocks are Early to Middle Carboniferous (ca 350 Ma to $335 \mathrm{Ma}$ ), or Early to Middle Permian (ca 265 Ma to $228 \mathrm{Ma}$ ). However, older ages, at ca $360 \mathrm{Ma}$ to $380 \mathrm{Ma}$, suggest that the oceanic crust might also contain Devonian parts (Fig. 5). The Eastern Ailaoshan is a Proterozoic basement overlain by remnants of Paleozoic to Early Mesozoic cover comparable to that of the SCB, and not a piece of Indochina as argued by Qi et al. (2014). The Jinping zone, formed by Paleozoic and Early Mesozoic sedimentary and magmatic rocks, corresponds to pieces of the cover of the Eastern Ailaoshan zone that has been extruded to the SE between the dextral Lao Meng-Dien Bien Phu and sinistral Sanjiahe faults. On the basis of this geodynamic 
reconstruction, the Triassic collision between the Indochina block and SCB can be considered as the consequence of the southwestward subduction and closure of the Paleotethys Ocean. This view is at variance from models that propose that the Indochina Block was subducting below the SCB in the Triassic (e. g. Wang et al., 2013) or that the collision occurred during the early Paleozoic (e.g. Metcalfe, 1996, 2013; Carter et al., 2001, Carter and Clift, 2008; Roger et al., 2008). Such a geodynamic framework is compared with the one recently proposed for the NW Vietnam orogen (Faure et al., 2014, 2016).

\subsection{Correlation with the NW Vietnam Belt}

The Western Ailaoshan magmatic arc is similar to the Sam Nua zone where Permian calc-alkaline volcanic and plutonic rocks are documented (e.g. Tran et al., 2008; Liu et al., 2012a; Roger et al., 2014; Fig. 13). The Central Ailaoshan ophiolitic mélange correlates to the Song Ma zone where Devonian-Carboniferous mafic and ultramafic blocks, radiolarian cherts, limestone are enclosed into a sheared and metamorphozed terrigenous matrix. (e. g. Lepvrier et al., 1997; Trung et al., 2006; Pham et al., 2008; Nguyen et al., 2013). The Eastern Ailaoshan zone extends in NW Vietnam as the Po Sen-Hoa Binh zone formed by a Paleoproterozoic gneissic and amphibolitic basement overlain by Paleozoic and Middle Triassic formations. Lastly, the Jinping zone represents the westward extension of the Son LaLai Chau zone of NW Vietnam. In this zone dominated by sedimentary rocks, the Late Permian alkaline mafic rocks of the Song Da rift are petrographically and geochronologically similar to those cropping out near Jinping, as already acknowledged (e.g. Wang et al., 2007; Balykin et al., 2010). However, the Tu Lê acidic volcanic and sedimentary rocks and the contemporaneous alkaline granites (e.g. Tran and Vu, 2011; Hieu et al., 2013) are absent in the Jinping zone, possibly due to its limited surface of exposure. The late Early Triassic-early Middle Triassic syncollisional felsic magmatism well developed near Lüchun is less abundant 
in NE Vietnam. But the foliated rhyolite, overlying the Song Ma ophiolitic mélange yielding zircon U/Pb ages around 252 $\pm 2 \mathrm{Ma}$ (Shi et al., 2015), are comparable to the Lüchun ones. In NW Vietnam, peraluminous and biotite granite plutons dated at ca 252-248 Ma (e.g. Liu et al., 2012a, Shi et al., 2015) belong to the same syn-collisional magmatism as in the Ailaoshan Belt. Furthermore, the Nam Co metamorphic rocks are not exposed in the Ailaoshan Belt. Due to the intensive Cenozoic shearing, the biotite-garnet micaschists (Wang and Ding, 1996) attributed to the Central Ailaoshan ophiolitic mélange might be equivalent to the Nam Co metamorphics of NW Vietnam. Moreover, the high-pressure metamorphic rocks, such as the eclogites and high-pressure granulites described in NW Vietnam (Nakano et al., 2008, 2010) have not been described yet in the Ailaoshan Belt.

\subsection{Elements of comparison of the Ailaoshan Belt with the NE Vietnam Belt}

East of the RRF, the NE Vietnam Belt that extends in SE Yunnan and SW Guangxi provinces of China, have been already analyzed in the frame of the Triassic tectonics (e.g. Lepvrier et al., 2011; Faure et al., 2014, 2016). From the SW to the NE, the following lithotectonic zones are recognized: i) the Day Nui Con Voi gneiss unit; ii) the Song Chay ophiolitic mélange; iii) the NE Vietnam nappe, and iv) the northern foreland outer zone (Fig. 13).

The Day Nui Con Voi (DNCV), characterized by gabbro, diorite and granodiorite plutons, has been interpreted as a magmatic arc. In SE Yunnan, the ductile deformation of the DNCV gneiss is characterized by a high angle foliation and a NW-SE striking subhorizontal stretching lineation (Fig. 10) obviously related to the left lateral shearing during the RRF Cenozoic activity (e.g. Leloup et al., 1995; Burchfiel et al., 2008). The gneiss is overlain by a Permian volcani-clastic series with grauwackes, siltstones, and volcanites that belong to a magmatic arc. The Song Chay ophiolitic mélange of NE Vietnam is not exposed there. 
Although this absence might result of the complex and incompletely deciphered Cenozoic structure of this area, we argue that the Song Chay suture does not extends northwestward in Yunnan, but abruptly terminates to the NW. However, the complete understanding of the detailed geometry requires additional mapping and structural analyses.

The NE Vietnam nappe develops widely in SE Yunnan but its structure is not analyzed here in detail. SE of Mengzi (Fig. 2), the Neoproterozoic (Sinian) sandstonemudstone, and the Cambrian black mudstone-siltstone formations are intensely deformed by intrafolial folds with NW-SE striking axes, or by NE-verging open folds. The flat lying or low dip cleavage complies better with a Triassic deformation age than with a Cenozoic one. To the north, the Paleozoic rocks of the NE Vietnam nappe overthrust northward the Middle Triassic turbidites of the Youjiang basin alike in NE Vietnam, where Devonian limestone overthrusts the Triassic turbidite of the Song Hien basin (Lepvrier et al., 2011; Fig. 15).

It is worth to note that basalts, sometimes pillowed, gabbros, and ultramafic rocks crop out in SE Yunnan, SE Guangxi, around Funing, and NE Vietnam, near Cao Bang, (Fig. 15). These rocks, named "Babu greenrocks" have been interpreted as ophiolites (Zhong et al., 1998; Cai and Zhang, 2009; Halpin et al., 2016). A thorough discussion of these interpretations is beyond the scope of this paper (see Faure et al., 2014 for details). Nevertheless, several lines of evidence such as the intrusive contacts of gabbro within Late Paleozoic limestone, the lack of deep sea sediments (e.g. radiolarian cherts, siliceous mudstone), and the lack of serpentinite masses suggest that the Babu Greenrocks might be related to a geodynamic event distinct from the subduction and collision of Indochina and SCB (Thanh et al., 2014). Thus, we favor an intraplate setting. In this view, the Late Permian magmatism in the Cao Bang Complex (Suoi Cun massif), in the range of 266-262 Ma (Tran et al., 2008b), as well as the Song Da complex could represent a distal part, laterally displaced by the RRF, of the Emeishan Large Igneous Province. Furthermore, rhyolite, rhyodacite, and 
acidic volcanic-sedimentary rocks are intercalated within the Song Hien turbidites. The rhyolite yields zircon U-Pb ages comprised between $251 \mathrm{Ma}$ and $248 \mathrm{Ma}$ in NE Vietnam (Tran et al., 2008b; Halpin et al., 403). These Early Triassic felsic rocks are generally grouped with the mafic ones, but the co-genetic relationships of the felsic and mafic rocks are unclear. Since they are geochronologically and geochemically similar to those of the Lüchun area in the Ailaoshan Belt, they might be also interpreted as formed in a syn-collisional setting. The high alumina Phia Bioc and Pia Ma granitic plutons dated at 248-242 Ma and 246 \pm 2 Ma, respectively (Roger et al., 2012; Chen et al., 2014) are petrologically and chronologically equivalent to the Heping ( $244 \pm 3 \mathrm{Ma}$ ), and Tontiange (247 $\pm 3 \mathrm{Ma}$ ) leucogranitic plutons of the Ailaoshan Belt (Lai et al. 2014b; Liu et al., 2014; Figs 5, 15).

\section{Conclusion}

In spite of the intense Cenozoic shearing, experienced by the Ailaoshan Belt, this area preserved well demonstrably lithological, structural, and magmatic features related to the preLate Triassic Indosinian orogeny. From the southwest to the northeast, the Western, Central, and Eastern Ailaoshan litho-tectonic zones corresponds to the magmatic arc, ophiolitic mélange, and deformed Precambrian basement and cover series, respectively. The Jinping zone, although isolated by Cenozoic strike-slip faults, belongs also to the sedimentary cover of a Precambrian continental basement. This zoning complies with a tectonic pattern characterized by a westward subduction (in the present coordinates) of a CarboniferousPermian oceanic domain, with possibly older parts, followed by the continental subduction of the South China Block. Our structural analysis at the outcrop, hand-sample, and microscopescale documents a top-to-the-NE ductile shearing. As indicated by the magmatic record, the onset of the collision between Indochina and South China blocks occurred in Early Triassic, 
around $250 \mathrm{Ma}$. The resulting crustal thickening triggered the dehydration melting of the Proterozoic basement, and led to the emplacement of per-aluminous felsic volcanites and twomica leucogranites in late Early to early Middle Triassic (ca 247-240 Ma). However, the topto-the-NE ductile shearing experienced by the late-collisional magmatic rocks shows that, as in most of the collisional belts, intracrustal deformation was going on after the welding of the continental masses. The Triassic structures of the Ailaoshan Belt extend to NW Vietnam, where the Song Ma suture is the continuation of the Central Ailaoshan ophiolitic mélange, and the Sam Nua magmatic arc is the extension of the Western Ailaoshan zone. The northward correlation of the Ailaoshan Belt with the Jinshajiang Belt is well acknowledged (e.g. Zhong et al., 2000). Recent geochronological and geochemical investigations support a similar geodynamic evolution scenario. In particular, the late-orogenic crustal melting at 247$246 \mathrm{Ma}$ (Zi et al., 2012) indicates that the collision took place during the Early Triassic. To the East, assuming that the NE and NW Vietnam belts were once connected before their Cenozoic disruption by the RRF, elements of correlation can be found in Hainan (Fig. 1; Faure et al., 2016), but a detail discussion of this question is beyond the scope of this paper.

Acknowledgements. This work was supported by the "Strategic Priority Research Program" of the Chinese Academy of Science (XDB03010802) and National Natural Science foundation of China (grants 41472193, 41225009, 41202079). A part of the expenses for M. F. have been also provided by UMR 7327 CNRS-Université d'Orléans. 
Balykin, P.A., Polyakov, G.V., Izokh, A.E., Hoa, T.T. Ngo Thi Phuong, Tran Quoc Hung, Petrova, T.E., 2010. Geochemistry and petrogenesis of Permian ultramafic-mafic complexes of the Jinping-Song Da rift (southeastern Asia). Russian Geology and Geophysics, 51, 611624.

Burchfiel, B.C., Chen, L., Wang, E., Swanson, E., 2008. Preliminary investigation into the complexities of the Ailaoshan and day Nui Con Voi shear zones od SE Yunnan and Vietnam. In Burchfiel, B.C. and Wang, E. eds., Investigations into the Tibetan Plateau. Geol. Soc. America Special Paper 444, 45-58.

Cai, J.X., Zhang, K.J., 2009. A new model for the Indochina and South China collision during the Late Permian to the Middle Triassic. Tectonophysics 467, 35-43.

Cai, Y., Wang, Y., Cawood, P., Fan, W., Liu, H., Xing, X., Zhang, Y., 2014. Neoproterozoic subduction along the Ailaoshan zone, South China: Geochronological and geochemical evidence from amphibolite. Precambrian Research 245, 13-28.

Carter, A., Roques, D., Bristow, C., Kinny, P., 2001. Understanding Mesozoic accretion in Southeast Asia: significance of Triassic thermotectonism (Indosinian orogeny) in Vietnam. Geology 29, 211-214.

Carter, A., Clift, P.D., 2008. Was the Indosinian orogeny a Triassic mountain building or a thermo-tectonic reactivation event? Comptes Rendus Geoscience 340, 83-93. 
Chen, Z., Lin,W., Faure, M., Lepvrier, C., Van Vuong, N., Van Tich, V., 2014.

Geochronology and isotope analysis of the Late Paleozoic to Mesozoic granitoids from northeastern Vietnam and implications for the evolution of the South China block. Journal of Asian Earth Sciences 86, 131-150.

Chen, C., Liu, JL., Tang, Y., Song, Z., Cao, S. 2015. Contrasting exhumation histories along a crustal-scale strike-slip fault zone: The Eocene to Miocene Ailao Shan-Red River shear zone in southeastern Tibet. J. Asian Earth Sci. 114, 174-187.

Fan, W.M., Wang, Y.J., Zhang, A.M., Zhang, F.F., Zhang, Y.Z., 2010. Permian arc-back-arc basin development along the Ailaoshan tectonic zone: geochemical, isotopic and geochronological evidence from the Mojiang volcanic rocks, Southwest China. Lithos119, $553-568$.

Faure, M., Lepvrier, C., Nguyen, VV., Vu, VT, Lin, W, Chen, Z. 2014. The South China block-Indochina collision: Where, when, and how? J. Asian Earth Sci. 79, 260-274.

Faure, M., Lin, W., Yang, C., Lepvrier, C. 2016. Triassic tectonics of the southern margin of the South China Block. Comptes Rendus Geoscience, 328, 5-14 doi.org/10.1016/j.crte.2015. 06.012 .

Findlay, R.H., 1997. The Song Ma anticlinorium, northern Vietnam: the structure of an allochthonous terrane containing an early Paleozoic island arc sequence. Journal of Asian Earth Sciences 15, 453-464. 
Findlay, R.H., Pham, T.T., 1997. The structural setting of the Song Ma region, Vietnam and the Indochina-South China plate boundary problem. Gondwana Research 1, 11-33.

Halpin, J.A., Tran, H.T., Lai, C.K., Meffre, S., Anthony J. Crawford, A.J., Zaw, K., 2016. U$\mathrm{Pb}$ zircon geochronology and geochemistry from NE Vietnam: A 'tectonically disputed' territory between the Indochina and South China blocks. Gondwana Research 34, 254-273.

Harrison, T.M., Leloup, P.H., Ryerson, F.J., Tapponnier, P., Lacassin, R., Chen, W., 1996. Diachronous initiation of transtension along the Ailao Shan-Red River shear zone, Yunnan and Vietnam. In: Yin, Ann, Harrison, T.M. (Eds.), The Tectonic Evolution of Asia. Cambridge University Press, pp. 208-226.

Hieu P. T., Chen, F., Nguyen, T.B.T., Nguyen, Q. C., Li, S.Q. 2013. Geochemistry and zircon $\mathrm{U}-\mathrm{Pb}$ ages and $\mathrm{Hf}$ isotopic composition of Permian alkali granitoids of the Phan Si Pan zone in northwestern Vietnam. Journal of Geodynamics, 69, 106-121.

Jian, P., Wang, X.F., He, L.Q., Wang, C.S., 1998. Geochronology of ophiolite rocks from the Ailaoshan suture, Yunnan province, southwestern Yunnan province, southwestern China: implications of Palaeotethyan evolution (in Chinese with English abstract). Geology and Mineral Resources of South China 1, 1-11.

Jian, P., Liu, D., Kroner, A., Zhang, Q., Wang, Y., Sun, X., Zhang, W., 2009a. Devonian to Permian plate tectonic cycle of the Paleo-Tethys Orogen in southwest China (I): geochemistry of ophiolites, arc/back-arc assemblages and within-plate igneous rocks. Lithos 113, 748-766. 
Jian, P., Liu, D., Kroner, A., Zhang, Q., Wang, Y., Sun, X., Zhang, W., 2009b. Devonian to Permian plate tectonic cycle of the Paleo-Tethys Orogen in southwest China (II): insights from zircon ages of ophiolites, arc/back-arc assemblages and within-plate igneous rocks and generation of the Emeishan CFB province. Lithos 113, 767-784.

Lai, C.-K., Meffre, S., Crawford, A.J., Zaw, K., Xue, C.-D., Halpin, J.A., 2014a. The Western Ailaoshan Volcanic Belts and their SE Asia connection: a new tectonic model for the Eastern Indochina Block. Gondwana Research 26, 52-74.

Lai, C.-K., Meffre, S., Crawford, A.J., Zaw, K., Halpin, J.A., Xue, C.-D., Salam, A., 2014b. The Central Ailaoshan ophiolite and modern analogs. Gondwana Research 26, 75-88.

Leloup, P.H., Lacassin, R., Tapponnier, P., Schärer, U., Zhong, D.L., Liu, X.H., Zhang, L.S., Ji, S.C., Phan, T.T., 1995. The Ailao Shan-Red River shear zone (Yunnan, China), Tertiary transform boundary of Indochina. Tectonophysics 251, 3-84.

Leloup, P.H., Amaud, N., Lacassin, R., Kienast, J.R., Harrison, T.M., Phan, T.T., Replumaz, A., Tapponnier, P., 2001. New constraints on the structure, thermochronology, and timing of the Ailao Shan-Red River shear zone, SE Asia. J. Geophysical Res. 106, B4, 6683-6732.

Lepvrier, C., Maluski, H., Van Vuong, Nguyen., Roques, D., Axente, V., Rangin, C., 1997. Indosinian NW-trending shear zones within the Truong Son belt (Vietnam): ${ }^{40} \mathrm{Ar}-{ }^{39} \mathrm{Ar}$ Triassic ages and Cretaceous to Cenozoic overprints. Tectonophysics 283, 105-127.

Lepvrier, C., Vuong, Nguyen Van, Maluski, H., Thi, Phan Truong, Tich, Vu Van, 2008. Indosinian tectonics in Vietnam. Comptes Rendus Geoscience 340, 94-111. 
Lepvrier, C., Faure, M., Van Vuong, Nguyen, Van Vu, Tich, Lin, W., Thang, Ta Trong, Phuong, Ta Hoa, 2011. North-directed Triassic nappes in Northeastern Vietnam (East Bac Bo). Journal of Asian Earth Sciences 41, 56-68.

Lin, T.H., Chung, S.L., Chiu, H.Y., Wu, F.Y., Yeh, M.W., Searle, M., Iizuka, Y, 2012. Zircon U-Pb and Hf isotope constraints from the Ailao Shan-Red River shear zone on the tectonic and crustal evolution of southwestern China. Chemical Geology 291, 23-37.

Liu, J.L, Tran, M., Tang, Y., Nguyen, Q.L., Tran, T.H., Wu, W., Chen, J., Zhang, Z., Zhao, Z., 2012a. Permo-Triassic granitoids in the northern part of the Truong Son belt, NW Vietnam: geochronology, geochemistry and tectonic implications. Gondwana Research 122, $628-644$.

Liu, J.L., Tang, Y., Tran, M.D., Cao, S.Y., Zhao, L., Zhang, Z.C., Zhao, Z.D., Chen, W., 2012b. The nature of the Ailao Shan-Red River (ASRR) shear zone: constraints from structural, microstructural and fabric analysis of metamorphic rocks from Diancang Shan, Ailao Shan and Day Nui Con Voi high grade massifs. J. Asian Earth Sci. 47, 231-251.

Liu, H.C., Wang, Y., Fan, W.M., Zi J.W., Cai Y.F., Y, G. L., 2014. Petrogenesis and tectonic implications of Late-Triassic high $\varepsilon N d(t)-\varepsilon H f(t)$ granites in the Ailaoshan tectonic zone (SW China). Science in China 57, 2181-2194.

Liu, J.L., Chen, X.Y., Tang, Y., Tran, M.D., Nguyen, Q.L., Wu, W.B., Tang, Y., Tran, M.D., 
Nguyen, Q.L., Zhang, Z.Z., Zhao, Z.D., 2015a. New tectono-geochronogical constraints on timing of shearing along the Ailao Shan-Red River shear zone: implications for genesis of Ailao Shan gold mineralization. J. Asian Earth Sci. 103, 70-86.

Liu, H., Wang, Y., Cawood, P.A., Fan,W., Cai, Y., Xing, X., 2015b. Record of Tethyan ocean closure and Indosinian collision along the Ailaoshan suture zone (SW China). Gondwana Research 27, 1292-1306.

Metcalfe, I., 1996. Pre-Cretaceous evolution of SE Asian terranes. In: Hall, R. \& Blundell, D. (Ed.), Tectonic Evolution of Southeast Asia. Geological Society Special Publication, vol. 106, pp. $97-122$.

Metcalfe, I., 2013. Gondwana dispersion and Asian accretion: tectonic and palaeogeographic evolution of eastern Tethys. Journal of Asian Earth Sciences 66, 1-33.

Nakano, N., Osanai, Y., Nguyen, T.M., Miyamoto, T., Hayasaka, Y., Owada, M., 2008.

Discovery of high-pressure granulite-facies metamorphism in northern Vietnam: constraints on the Permo-Triassic Indochinese continental collision. Comptes Rendus Geosciences 340, $127-138$.

Nakano, N., Osanai, Y., Sajeev, K., Hayasaka, Y., Miyamoto, T., Minh, Nguyen Thi, Owada, M., 2010. Triassic eclogite from northern Vietnam: inferences and geological significance. Journal of Metamorphic Geology 28, 59-76.

Nguyen, V.V., Hansen, B., Wemmer, K., Lepvrier, C., Vu, V.T., Ta, T.T., 2013. U/Pb and 
$\mathrm{Sm} / \mathrm{Nd}$ dating on ophiolitic rocks of the Song Ma suture zone (northern Vietnam): evidence for Upper Paleozoic Paleotethyan lithospheric remnants. J. of Geodynamics 69, 140-147.

Pham, T.H., Chen, F.K., Wang, W., Tam, B.M., Nguyen, T.B.T., Hoa, T.X., Li, X.H., 2008. Formation ages of granites and metabasalts in the Song Ma belt of northwestern Vietnam and their tectonic implications. Conference Gondwana 13, Dali, China, Abstracts vol., 163.

Qi, X., Zeng, L.,Zhu, L., Hu, Z., Hou, K., 2012. Zircon U-Pb and Lu-Hf isotopic systematics of the Daping plutonic rocks: Implications for the Neoproterozoic tectonic evolution of the northeastern margin of the Indochina block, Southwest China. Gondwana Research 2, 180193.

Qi, X., Santosh, M., Zhua, L., Zhao, Y., Zhaocuo Hu, Z., Chao Zhang, C., Ji, F. 2014. MidNeoproterozoic arc magmatism in the northeastern margin ofthe Indochina block, SW China: Geochronological and petrogeneticconstraints and implications for Gondwana assembly. Precambrian Res., 245, 207-224.

Roger, F., Jolivet, M., Malavieille, J., 2008. Tectonic evolution of the Triassic fold belts of Tibet. C. R. Geoscience 340, 180-189.

Roger, F., Maluski, H., Lepvrier, C., Vu Van, T., Paquette, J.-L., 2012. LA-ICPMS zircons $\mathrm{U} / \mathrm{Pb}$ dating of Permo-Triassic and Cretaceous magmatisms in Northern Vietnam-geodynamic implications. Journal of Asian Earth Sciences 48, 72-82. 
Roger, F., Jolivet, M., Maluski, H., Respaut, J.P., Münch, P., Paquette, J.L. Vu V.T., Nguyen, V.V., 2014. Emplacement and cooling of the Dien Bien Phu granitic complex: Implications for the tectonic evolution of the Dien Bien Phu Fault (Truong Son Belt, NW Vietnam). Gondwana Research 26, 785-801.

Shen, S.Y., Wei, Q.R., Cheng, H.L., Mo, X.X., 1998. Tectonomagmatic types of volcanic rocks in Ailaoshan-Lixianjiang Belt, Nu River-Lancang River-Jinsha River area in China (in Chinese with English abstract). Journal of Mineralogy and Petrology 18, 18-24.

Searle, M.P., 2006, Role of the Red River Shear zone, Yunnan and Vietnam, in the continental extrusion of SE Asia: Journal of the Geological Society163, 1025-1036.

Searle, M., Yeh, M.W., Lin, T.H., Chung, S.L., 2010. Structural constraints on the timing of left-lateral shear along the Red River shear zone in the Ailao Shan and Diancang Shan Ranges, Yunnan, SW China. Geosphere 6, 316-338.

Schärer, U., Zhang, LS., Tapponnier, P., 1994. Duration of strike-slip movements in large shear zones: The Red River belt, China. Earth Planet. Sci. Letters, 126, 379-397.

Shi, M.F., Lin, F.C., Fan, W.Y., Deng, Q., Cong, F., Tran, M.D., Zhu, H.P., Wang, H., 2015. Zircon U-Pb ages and geochemistry of granitoids in the Truong Son terrane, Vietnam: Tectonic and metallogenic implications. J. Asian Earth Sciences 101, 101-120.

Tang, Y., Liu, J.L., Tran, M.D., Song, Z.J., Wu, W.B., Zhang, Z.C., Zhao, Z.D., Chen, W., 2013. Timing of left-lateral shearing along the Ailao Shan-Red River shear zone: constraints 
from zircon $\mathrm{U}-\mathrm{Pb}$ ages from granitic rocks in the shear zone along the Ailao Shan Range, Western Yunnan, China. Int. J. Earth Sci. 102, 605-626.

Tapponnier, P., Lacassin, R., Leloup, P.H., Schärer, U., Zhong, D.L., Liu, X.H., Ji, S.C., Zhang, L.S., Zhong, J.Y., 1990. The Ailao Shan/Red River metamorphic belt: Tertiary left lateral shear between Indochina and South China. Nature 343, 431-437.

Thanh, N.X., Hai, T.T., Hoang, N., Lan, V.Q., Kwon, S., Itaya, T., Santosh, M., 2014. Backarc mafic-ultramafic magmatism in Northeastern Vietnam and its regional tectonic significance. Journal of Asian Earth Sciences 90, 45-60.

Tran, T.H., Tran T.A., Ngo, T.P., Izokh, A.E., Polyakov, G.V., Balykin, P.A., Lan, C.Y., Hoang, H.T., Bui, A.N., Pham T.D., 2004. Gabbro-syenite associations of East Bac Bo structures: evidences of intra-plate magmatism? Journal of Geology, B 23, 12-25.

Tran, T.H., Tran, T.A., Ngo, T.P., Pham, T.D., Tran, V.A., Izokh, A.E., Borisenko, A.S., Lan, C.Y., Chung, S.L., Lo, C.H., 2008a. Permo-Triassic intermediate-felsicmagmatism of the Truong Son belt, eastern margin of Indochina. Comptes Rendus Geoscience 340, 112-126.

Tran, T.H., Izokh, A.E., Polyakov, G.V., Borisenko, A.S., Ngo, T.P., Balykin, P.A., Tran, T.A., Rudnev, S.N., Vu, V.V., Bui, A.N., 2008b. Permo-Triassic magmatism and metallogeny of Northern Vietnam in relation to the Emeishan plume. Russian Geology and Geophysics 49, $480-491$. 
Tran, V.T., Vu, K., Vu (Eds.), 2011. Geology and Earth Resources of Vietnam, General Dept of Geology, and Minerals of Vietnam, Hanoi, Publishing House for Science and Technology, p. 634.

Trung, N., Tsujimori, T., Itaya, T., 2006. Honvang serpentinite body of the Song Ma fault zone, Northern Vietnam: a remnant of oceanic lithosphere within Indochina and South China suture. Gondwana Research 9, 225-230.

Wang, P.L., Lo, C.H., Chung, S.L., Lee, T.Y., Lan, C.Y., 2000.Onset timing of left-lateral movement along the Ailaoshan-Red River Shear Zone: 40Ar/39Ar dating constraint from the Nam Dinh Area, northeastern Vietnam. Journal of Asian Earth Sciences 18, 281-292.

Wang Y.Z. and Ding J., 1996. Structural Deformation and evolution of the Medium-to HighGrade metamorphic rock series in the Ailao Mountains, Yunnan. Tethyan Geology. 20, 52-69.

Wang, C.Y., Zhou, MF., Qi, L., 2007. Permian flood basalts and mafic intrusions in the Jinping (SW China)-Song Da (northern Vietnam) district: Mantle sources, crustal contamination and sulfide segregation. Chem. Geol., 243, 317-343.

Wang, Y.J., Fan, W., Zhang, G., Zhang, Y., 2013. Phanerozoic tectonics of the South China Block: key observations and controversies. Gondwana Res. 23, 1273-1305.

Yumul, G.P., Zhou, M.F., Wang, Y.C., Zhao, T.P., Dimalanta, C.B., 2008. Geology and 
geochemistry of the Shuanggou opiholite (Ailao Shan ophiolitic belt), Yunnan province, SW China: evidence for a slow-spreading oceanic basin origin. Journal of Asian Earth Sciences $32,385-395$.

Zhong, D., 2000. Paleotethysides in West Yunnan and Sichuan, China. Science Press, Beijing, 248 p.

Zi, J.W., Cawood, P.A., Fan, W.M., Wang, Y.J., Tohver, E., McCuaig, T.C., Peng, T.P., 2012. Triassic collision in the Paleo-Tethys Ocean constrained by volcanic activity in SW China. Lithos 144-145, 145-160. 
Figure Captions

Fig. 1: Tectonic map of SE Asia locating the Ailaoshan Belt within the Triassic orogens separating the South China Block and Indochina Block. SCS: Song Chay suture; SMS: Song Ma suture; JSJS: Jinshajiang suture; ELIP: Emeishan Large Igneous Province; RRF: Red River fault; DBF: Bien Bien Phu fault; LMS: Longmenshan; TLF: Tanlu fault; BNS: Bangong-Nujiang suture.

Fig. 2: Geological map of the Ailaoshan Belt, and the northwestern termination of the NE Vietnam belt. RRF: Red River Fault; SCF: Song Chay Fault. Letters A, B, C, D, E, and F refer the foliation and lineation stereographic diagrams of Fig. 10.

Fig. 3: Synthetic columns for the four litho-tectonic zones defined in the Ailaoshan Belt.

Fig. 4: Field pictures of the Western Ailaoshan zone, all pictures are from Mojiang area. A: Turbididic series; B: Conglomerate with volcanic elements and limestone, note the ductile deformation of the pebble with foliation plane parallel to the hammer; C: Grauwacke- black siltstone alternations; D: basaltic pillow lava.

Fig. 5: Compilation of the available geochronological data in the Ailaoshan Belt. (1): Liu et al. (2015); (2): Lai et al. (2014a); (3): Lai et al. (2014b); (4): Liu et al. (2014); (5): Lin et al. (2012); (6): Cheng and Mao (2010); (7): Fan et al. (2010); (8): Jian et al. (2010a); (9): Jian et al. (2010b). 
Fig. 6: Field pictures of the Central Ailaoshan ophiolitic mélange. A: red siliceous mudstone; B: basaltic lava; C: sandstone block in pelitic matrix; D: limestone block in a sandstonesiltstone matrix; E: mélange matrix composed of sandstone mudstone alternations.

Fig. 7: Field pictures of the Eastern Ailaoshan and Jinping zones, A: flat-lying foliation in the Paleoproterozoic gneiss and amphibolite basement of the Eastern Ailaoshan zone; B and C: late Permian alkaline volcanites of the Jinping zone similar to the Song Da zone of NW Vietnam, B: pillow lava, C: volcanic breccia; D: Devonian turbidite near Jinping forming the substratum of the Permian rift.

Fig. 8: Cross sections throughout the Ailaoshan Belt located in Fig. 2. RRF: Red River fault, AF: Ailaoshan fault.

Fig. 9: Outcrop-scale deformations attributed to the Cenozoic (A, B, C) and pre-Late Triassic (D, E) events. A: Late Triassic sandstone with subvertical cleavage (S2) in the Central Ailaoshan zone, close to the Ailaoshan fault; B: detail of the bedding (S0)- cleavage (S2) relationships in Late Triassic red sandstone-siltstone formation; C: upright fold without axial planar cleavage in Permian sandstone in the Western Ailaoshan attributed to the Cenozoic deformation; D: stretching lineation represented by elongated clasts in limy pelite in the Middle Triassic cover of the Eastern Ailaoshan zone; E: NE-verging fold coeval with a S1 cleavage in the Middle Triassic limestone cover of the Eastern Ailaoshan zone.

Fig. 10: Stereographic plots (Schmidt diagram, lower hemisphere) of the planar (crosses) and linear (dots) elements observed in the pre-Late Triassic rocks of the Ailaoshan Belt. Location in fig. 2, n: number of measurements. A: Northern part of the Central Ailaoshan ophiolitic 
mélange. B: Northern part of the Eastern Ailaoshan zone. C: Northern part of the Central Ailaoshan ophiolitic mélange. D: Southern part of the Eastern Ailaoshan zone. E: Middle part of the Western Ailaoshan magmatic arc. F: Northern termination of the Dai Nuy Con Voi.

Fig. 11: Examples of outcrop-scale deformation structures related to the pre-Late Triassic tectonics in the Central Ailaoshan ophiolitic mélange. A: intrafolial fold in the foliated (S0-1) matrix; B: foliated serpentinite block in the mélange with top-to-the NE sigmoidal structure; C: intrafolial fold in siliceous mudstone; D: sigmoidal pebble in Permian conglomerate with asymmetric pressure shadows indicating a top-to-the NE shearing; E: bedding (S0) transposed in the $\mathrm{S} 1$ foliation in the silty matrix of the mélange.

Fig 12: Microscope-scale picture of ductile deformation in the pre-Late Triassic rocks. A-C: sedimentary cover of the Eastern Ailaoshan gneissic basement. D-F: sandstone matrix of the ophiolitic mélange. Thin sections are perpendicular to the foliation, and parallel to the stretching lineation. All the kinematic indicators show a top-to-the-NE shearing. A: ultramylonitic quartzite; B: sheared quartzite; C: ultramylonitic sandstone; D: ultramylonitic sandstone; E: mylonitic sandstone F: mylonitic sandstone

Fig. 13: Microscope-scale picture of the ductile deformation in the late Early Triassic volcanites and sedimentary rocks. Thin sections are perpendicular to the foliation, and parallel to the stretching lineation. All the kinematic indicators show a top-to-the-NE shearing. A: foliated rhyolite with rotated fractured clasts and sericite pressure shadows; B: volcanicsedimentary schist with sigmoidal opaque minerals in sheared matrix; C: foliated quartzite with sigmoidal quartz grains; D: mm-sized quartz grain surrounded with white mica pressure 
shadows in sandstone; E: foliated sandstone with asymmetric pressure shadows; F: sheared sandstone with dynamically recrystallized quartz grains and oblique shape fabric.

Fig 14: Crustal-scale interpretative cross section of the Ailaoshan Belt after the Triassic (Indosinian) collision, and before the Cenozoic strike slip faulting showing a polyphase thrust sheet imbrication. The ca 245 Ma peraluminous granite and rhyolite develop in the lower plate during the emplacement of the Central Ailaoshan ophiolitic mélange and collision with the Indochina Block. The ductile deformation recorded by the syn-collisional magmatic rocks and the Middle Triassic (T2) sedimentary rocks of the Jinping and Eastern Ailaoshan zones argue for a polyphase deformation.

Fig. 15. Correlation map between the Ailaoshan Belt, the NW, and the NE Vietnam Belts. WAS: Western Ailaoshan, CAS: Central Ailaoshan, EAS: Eastern Ailaoshan, JP: Jinping zone, PS: Po Sen, DNCV: Day Nui Con Voi, CB: Cao Bang, SCS: Song Chay Suture, HB: Hoa Binh, SD: Song Da, SMS: Song Ma Suture. 


\section{Highlights}

- The collision between Indochina and S. China blocks was accommodated by a southwestward subduction

- A ductile top-to-the-NE ductile shearing characterizes the Ailaoshan Belt

- The Early Triassic collision triggered late-orogenic crustal melting, followed by Middle Triassic top-to-the-NE shearing

- A detail tectonic correlation between the Ailaoshan and Vietnam belts is provided 


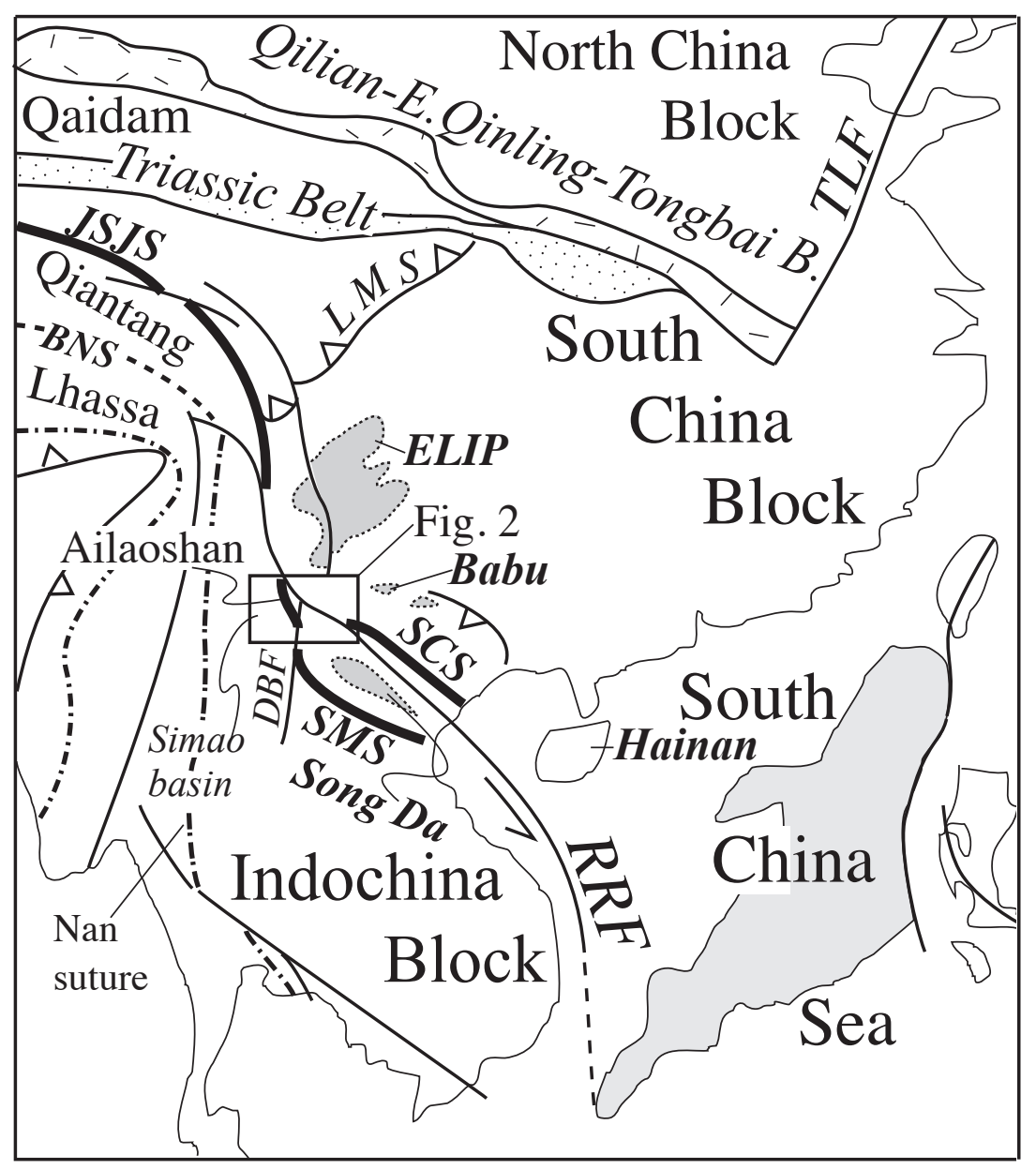

Fig. 1 


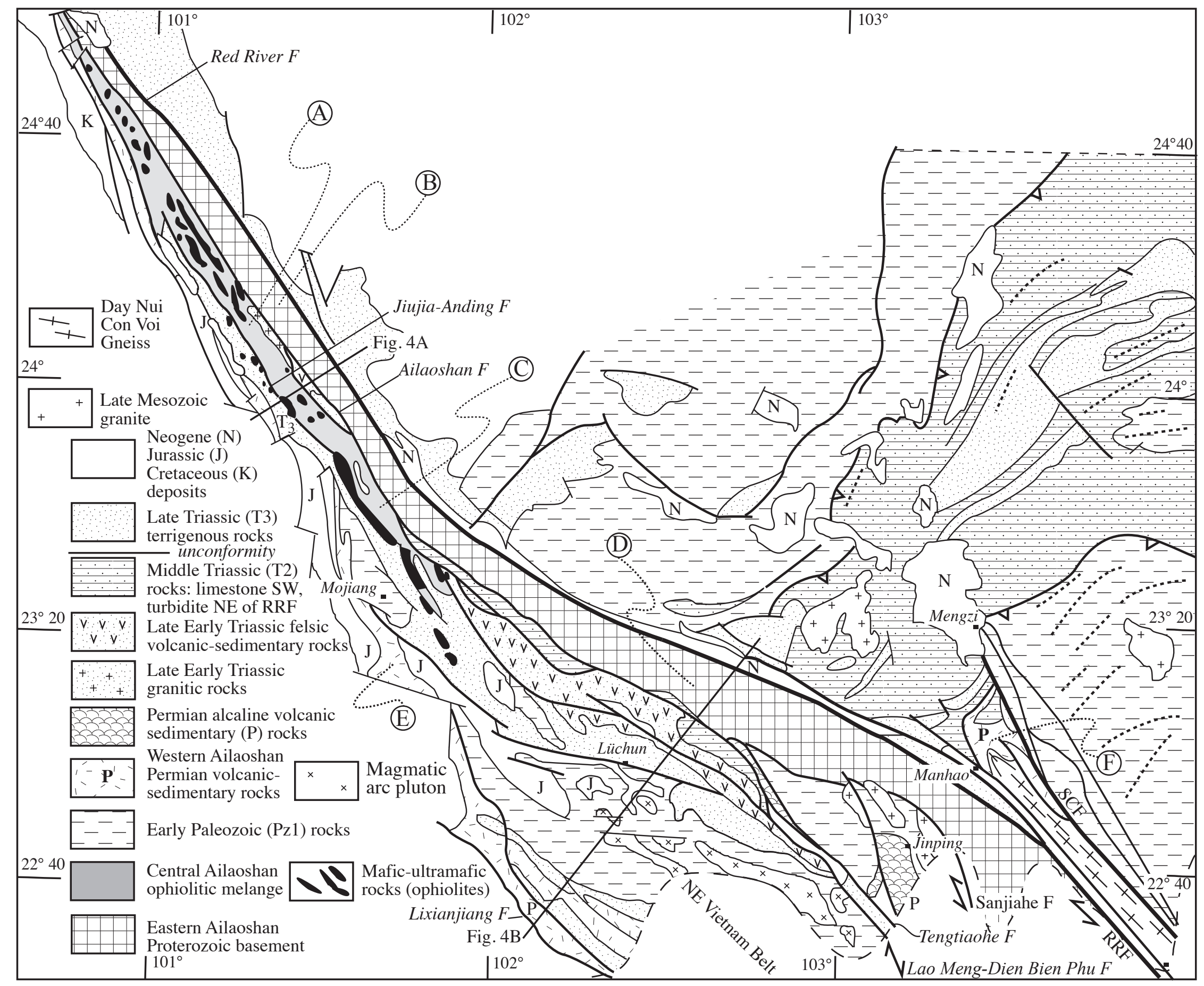




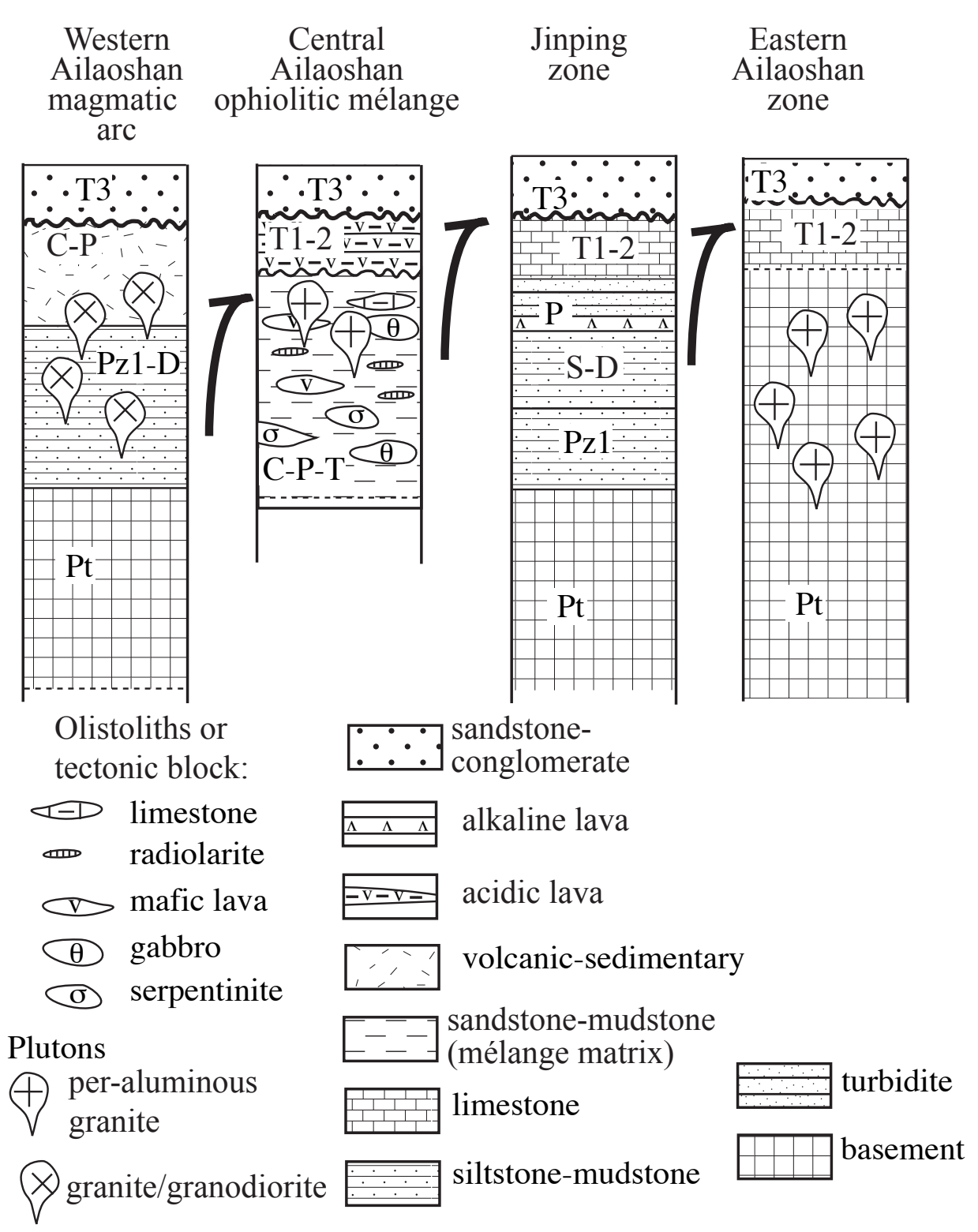




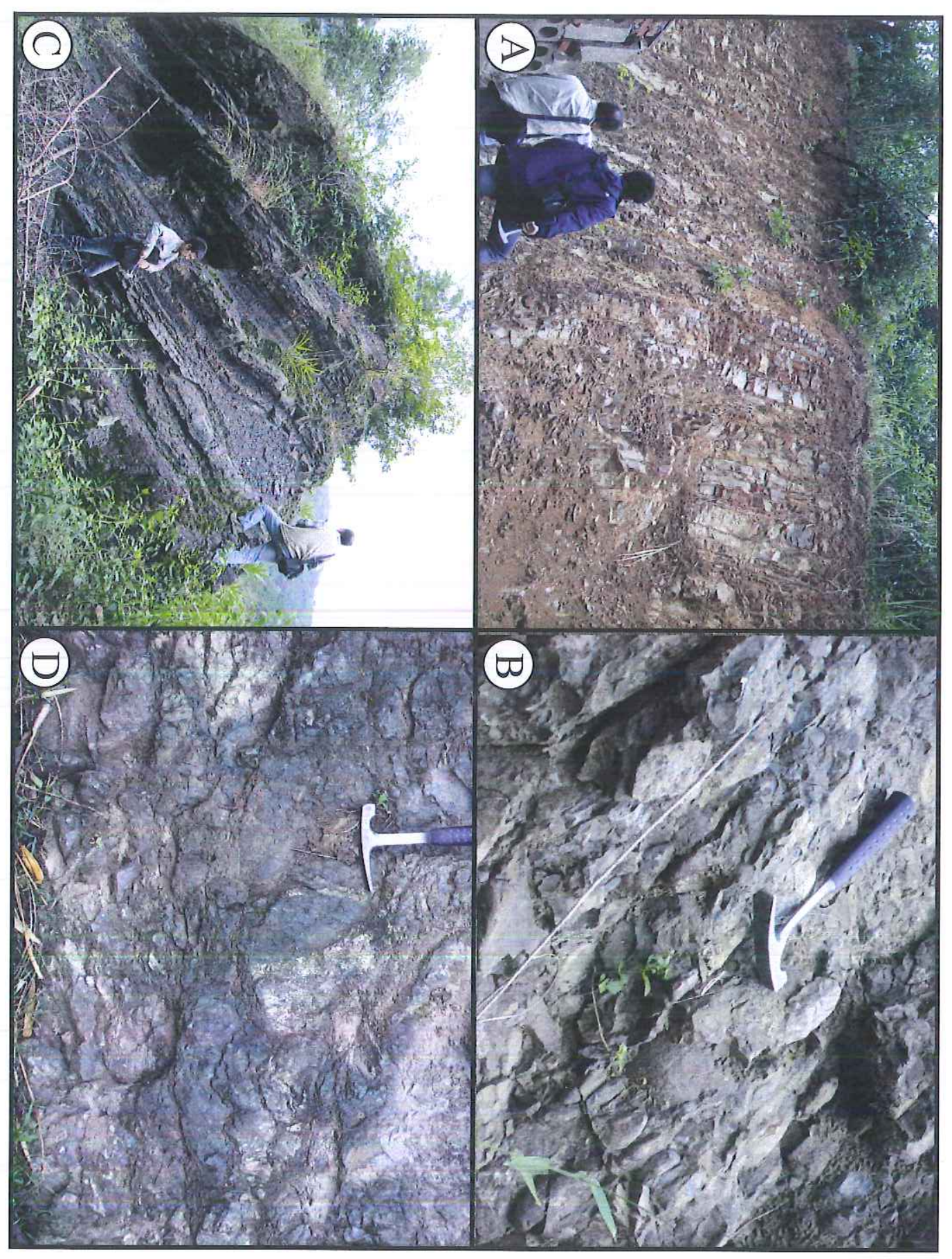

Tृ?

$+$ 


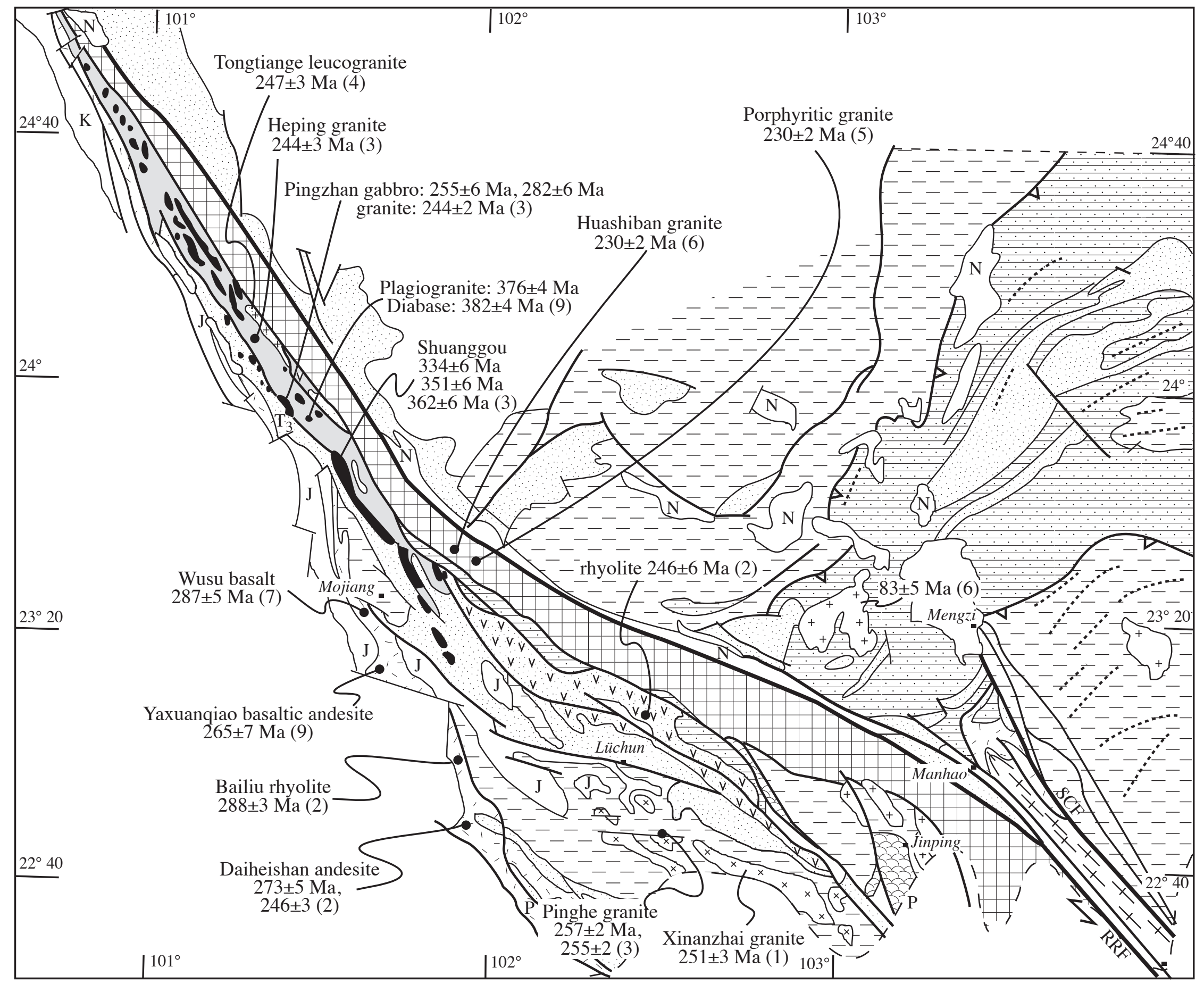




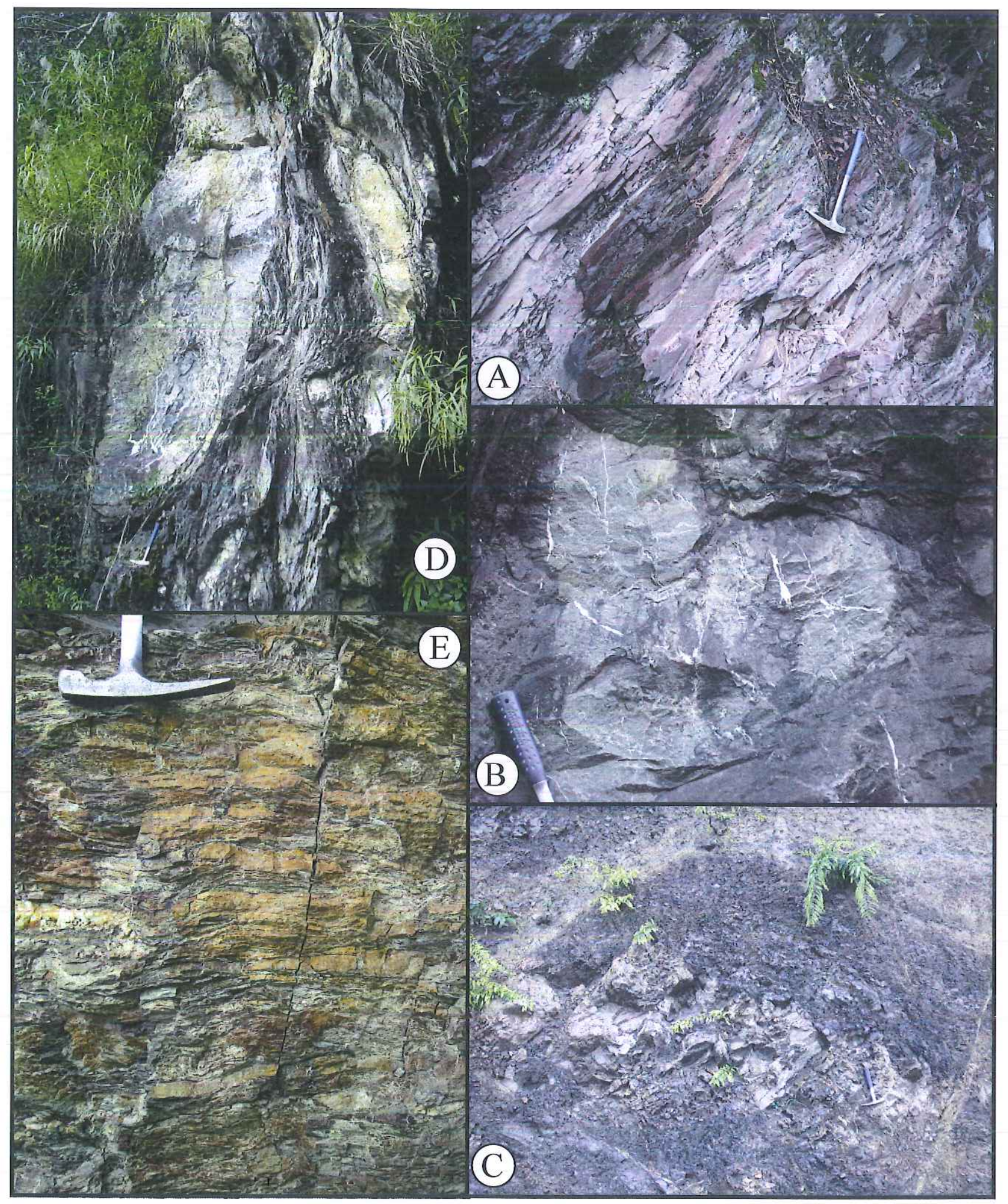

Fig. 6 


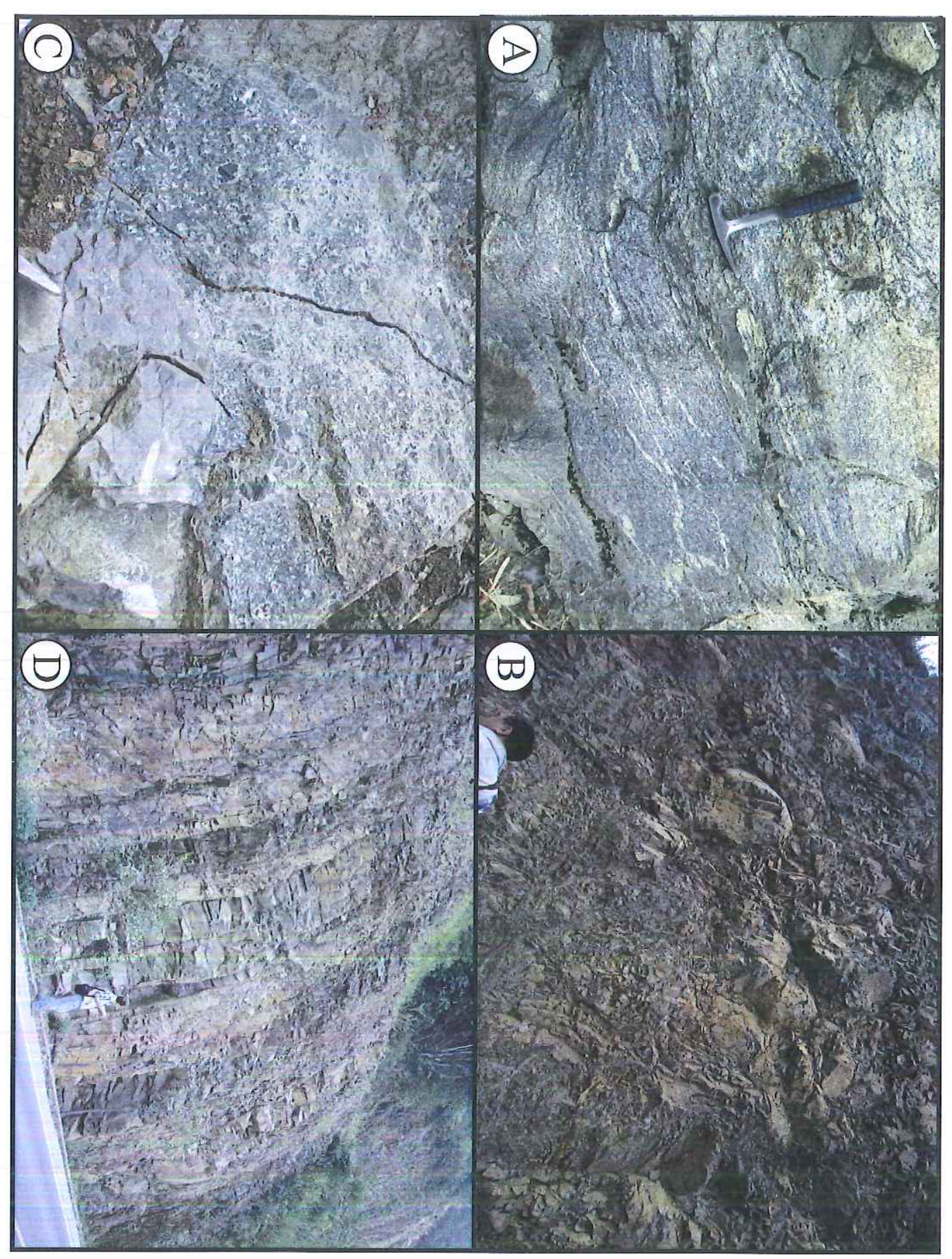




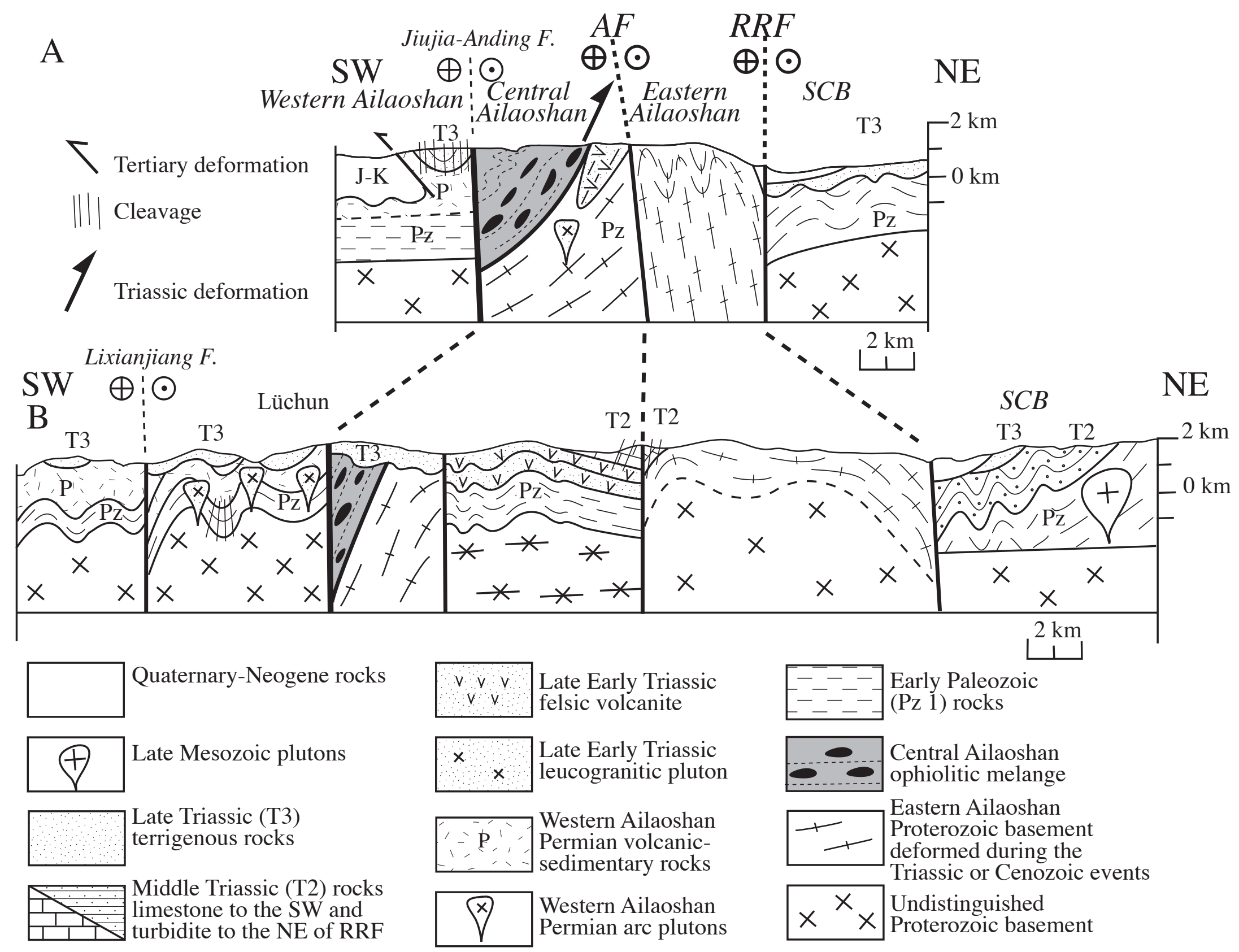




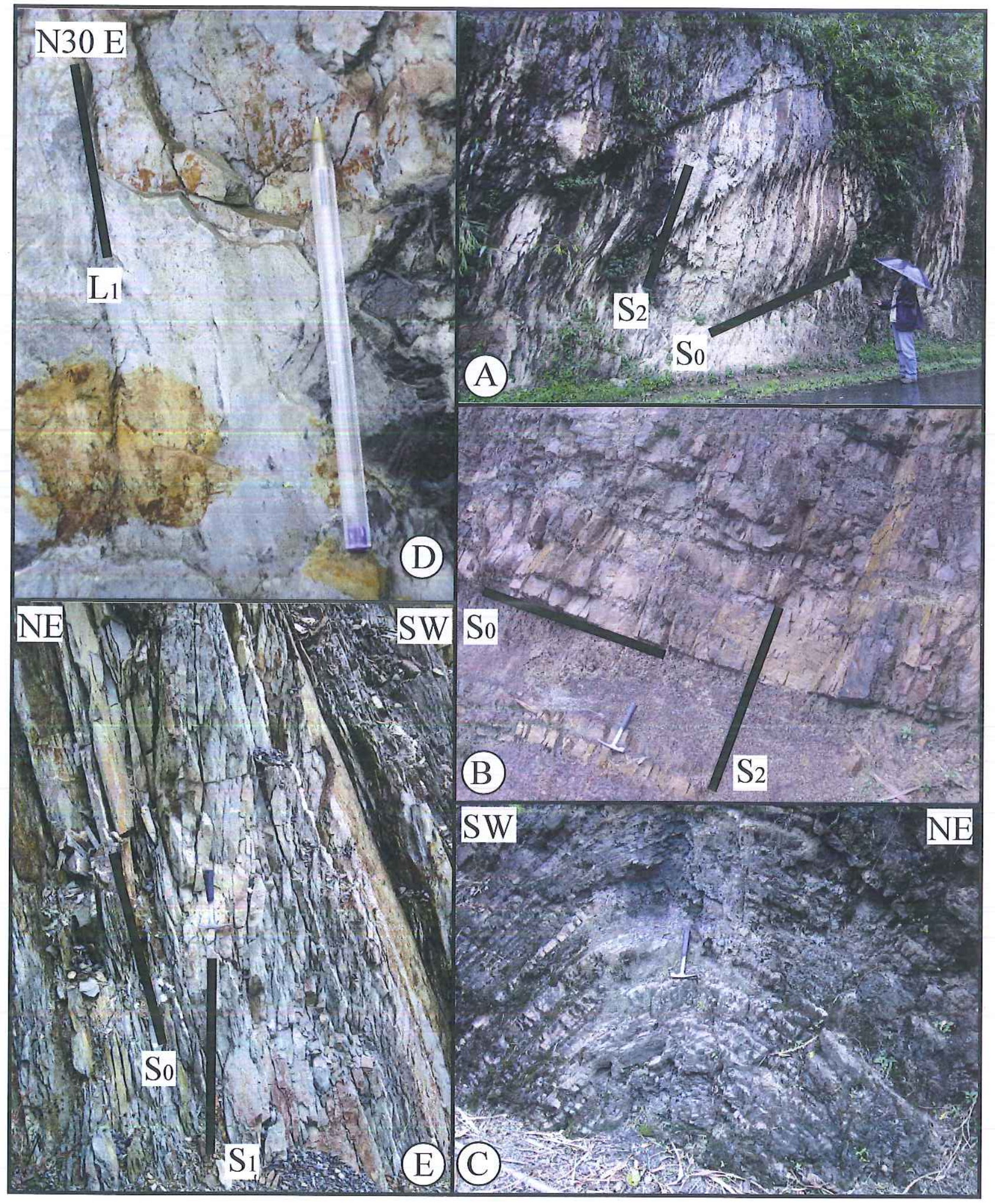

Fig. 9 
A: N. Central Ailaoshan

+ Foliation pole $(\mathrm{n}=17)$

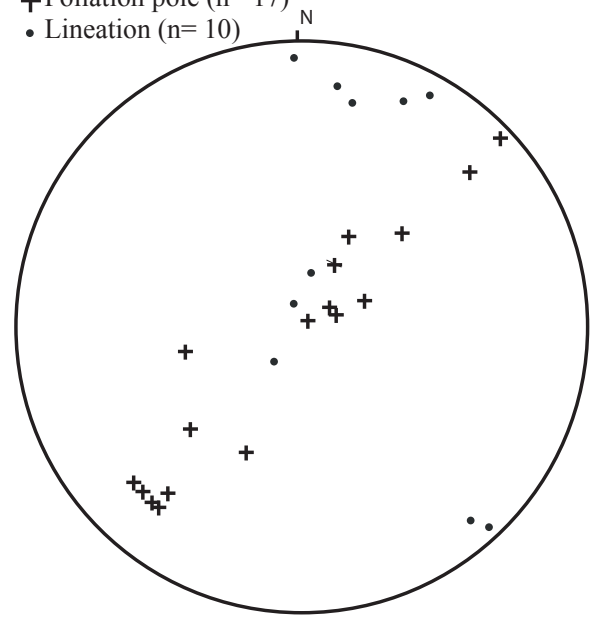

C: S. Central Ailaoshan

+ Foliation pole $(\mathrm{n}=17)$
- Lineation $(\mathrm{n}=15)$

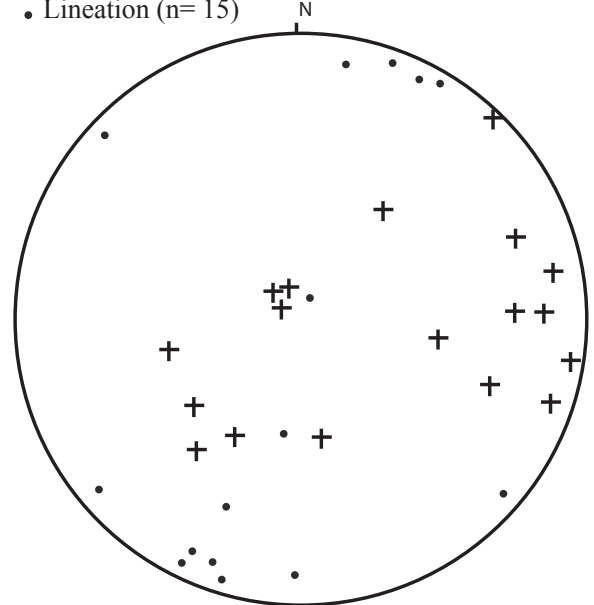

E: W. Ailaoshan

+ Foliation pole $(n=29)$

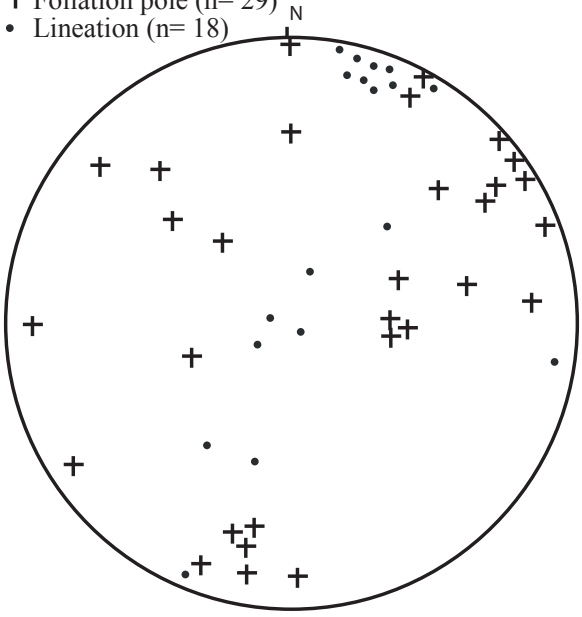

B: N. Eastern Ailaoshan

+ Foliation pole $(\mathrm{n}=20)$

- Lineation ( $\mathrm{n}=15)$

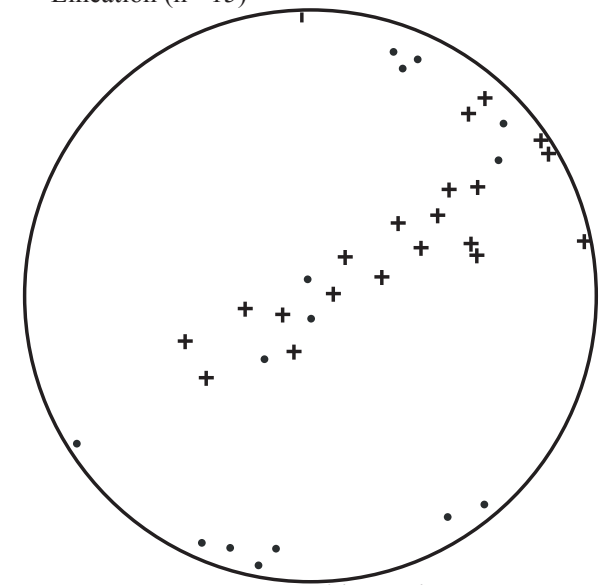

D: S. Eastern Ailaoshan

+ Foliation pole $(n=20)$

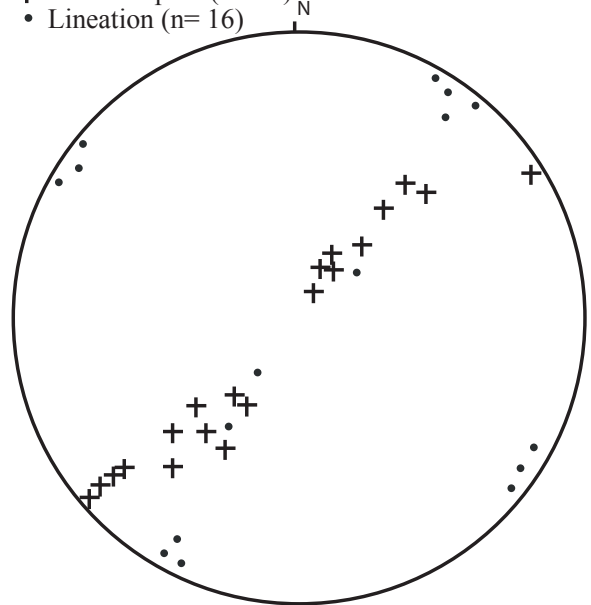

F: N. Dai Nuy Con Voi

+ Foliation pole $(\mathrm{n}=17)$

- Lineation (n=12)

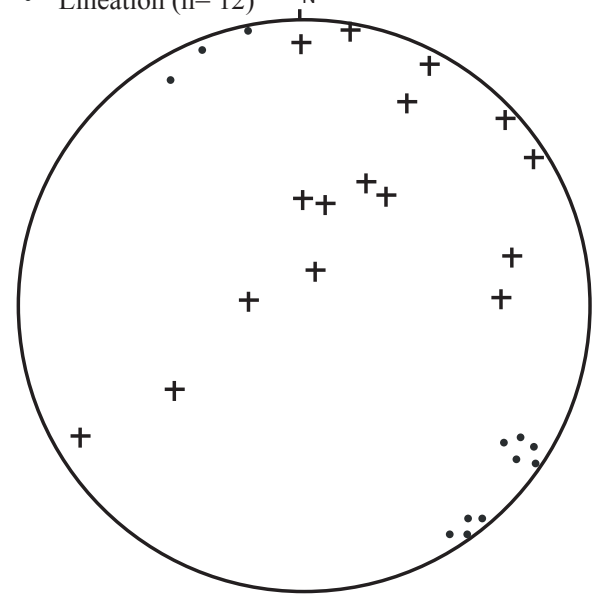

Fig. 10 


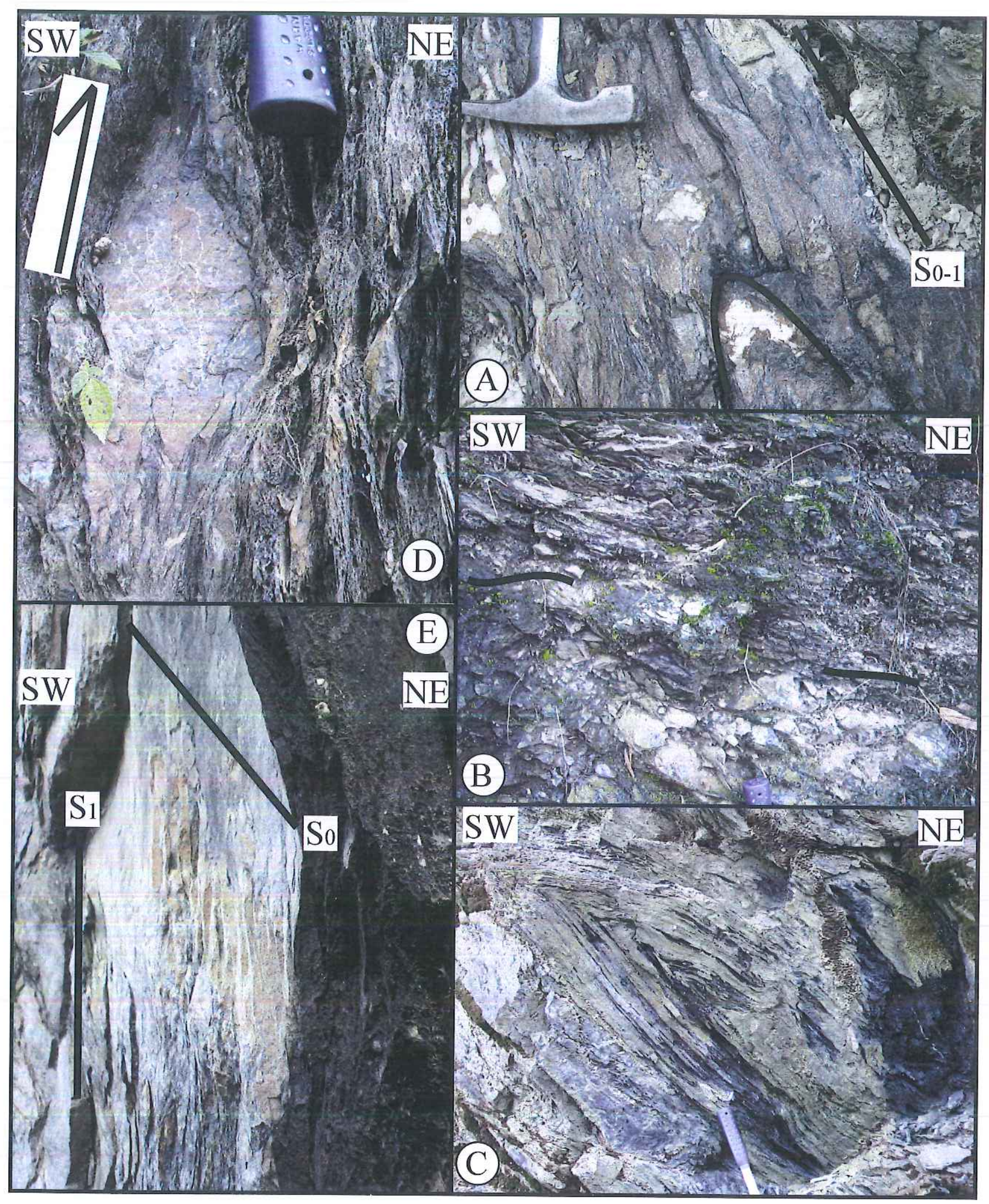

Fig. 11 


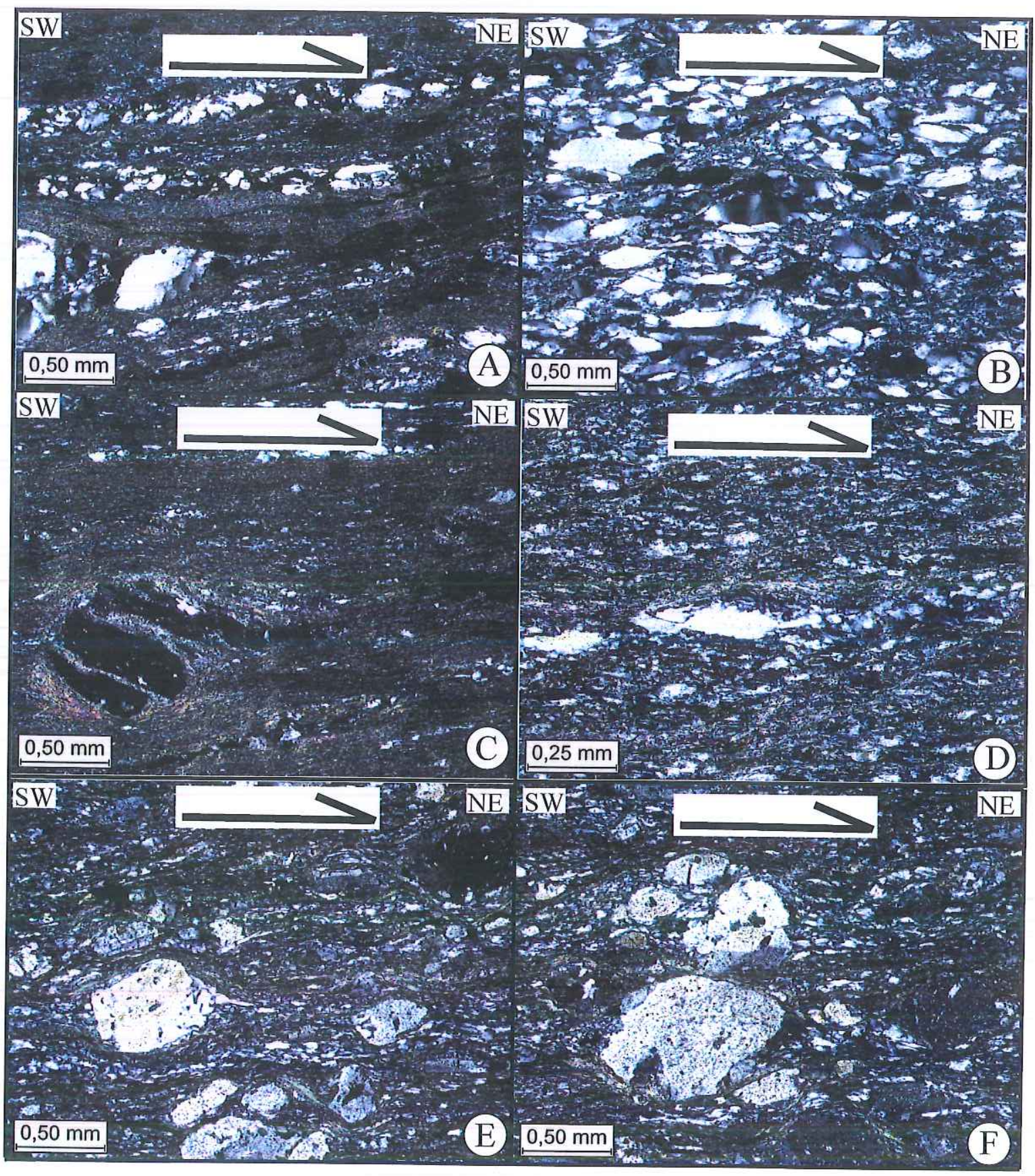

Fig. 1 


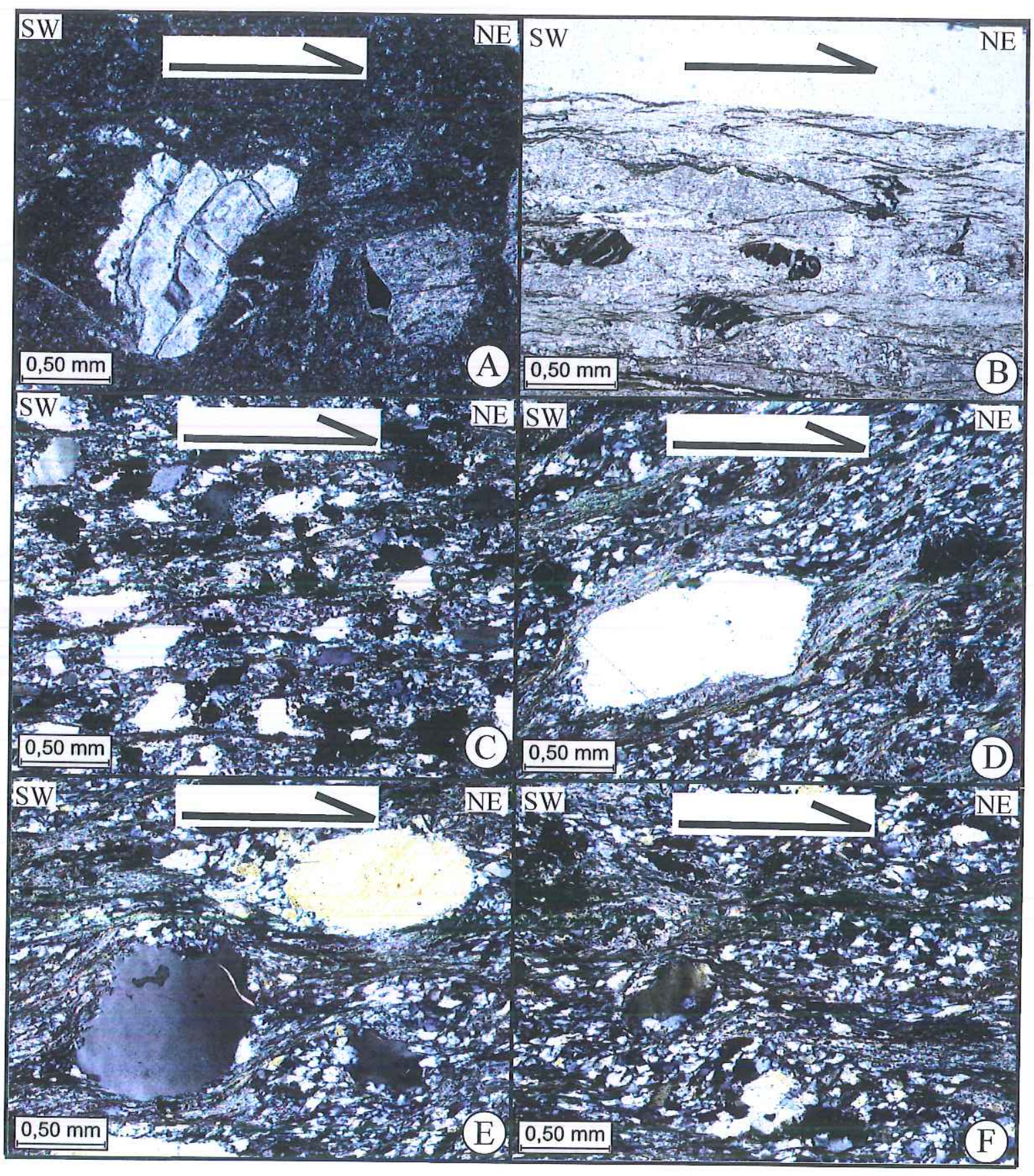

Fig. $\times 3$ 


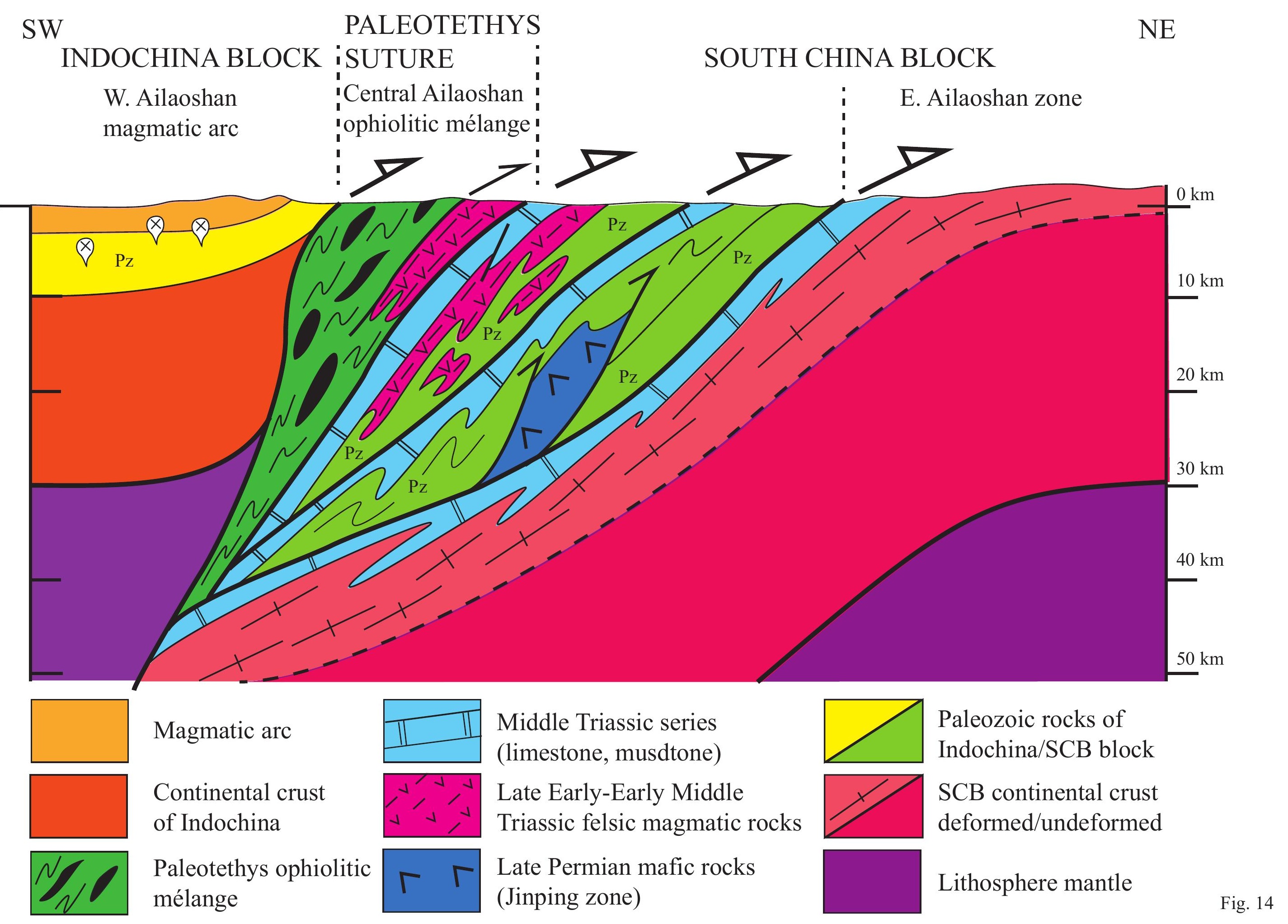


